\title{
Türk Modernleşmesi, Pozitivizm ve Sosyoloji
}

\author{
Turkish Modernization, Positivism and Sociology
}

Bekir BALKIZ ${ }^{*}$

Öz: $\mathrm{Bu}$ makalede, esas olarak Osmanl1-Türk toplumunun modernleşme sürecinin temel özelliklerine değinilerek, bu süreçte pozitivizmin ve pozitivist etki altında biçimlenmiş sosyolojinin nasıl bir rol oynadığı üzerinde durulacaktır. Osmanlı-Türk toplumunun modernleşme/modernleştirilmesi sürecinde bir toplum ve siyaset tasavvuru, bir dünya görüşü ve bir zihniyet modeli olarak pozitivist düşünce, başlangıcından beri bu sürecin aktörlerinin neredeyse tamamının geliştirdikleri toplum ve siyaset projelerinin arka planını belirlemiştir. Cumhuriyet Dönemi Türkiye'sinde ise pozitivist sosyoloji, modernleşmenin önemli kaynaklarından birini oluşturmuş ve modern ulus-devletin inşâ sürecinde de resmî ideolojinin kurucu öğelerinin önemli bir bölümüne kaynak teşkil etmiş̧ir. Bu açıdan, baştan itibaren Türkiye'de resmî sosyoloji her zaman siyasal bir içeriğe sahip olmuş ve siyasal bir işlev üstlenmiş ve çoğu zaman da devlet ideolojisinin üretilmesinin araçlarından biri olarak tasavvur edilmiştir. Bu makale yukarıda işaret edilen temalar doğrultusunda, genel olarak Türk modernleşmesi, pozitivizm ve sosyoloji ilişkisinin tartışıldığı bir değerlendirmeyle son bulacaktır.

Anahtar sözcükler: Osmanl1-Türk Modernleşmesi, Pozitivizm, Pozitivist Sosyoloji, Cumhuriyet İdeolojisi, Sosyoloji ve İdeoloji

Abstract: This article will mainly focus on the main features of the modernization process of the Ottoman-Turkish society and what role is played by sociology which is shaped by positivism and positivist influence. Positivist thought, which has been a concept of society and politics, a world-view and a model mentality during the modernization process of the Ottoman-Turkish society, has determined the background of the social and political projects developed by almost all actors of this process from the start. During the Republican era of Turkey, positivist sociology has formed an important source for modernization and served as a basis for a significant part of the founding elements of the official ideology during the establishment of the modern nation-state. In this respect, official sociology in Turkey has always had political contents, served a political function and has mostly been envisaged as a means of production for the ideology of the state. This article, in view of the themes stated above, shall end with an assessment in which Turkish modernization, the relationship between positivism and sociology will be generally discussed.

Keywords: Ottoman-Turkish Modernization, Positivism, Positivist Sociology, Republican Ideology, Sociology and Ideology

\section{Giriş}

'Türk modernleşmesi' Osmanlı İmparatorluğu'nda 18. yüzyılın sonlarından itibaren başlayan ve esas olarak Cumhuriyetin kuruluşuyla ivme kazanan, bir bakıma halen devam etmekte olan Osmanl1-Türk toplumunun Batılılaş(tırıl)ması çabalarını tanımlamak için kullanılan bir kavram-

\footnotetext{
*Yrd. Doç. Dr., Ege Üniversitesi, Edebiyat Fakültesi, Sosyoloji Bölümü, İzmir. balkiz07@yahoo.com.tr.
} 
dır. Aşağı yukarı 200 yıllık bir geçmişi olan bu süreçte, Batının kendi tarihine özgü dinamiklerinden doğan ve özü gereği Batıya ait olan modern toplumsal, siyasal ve ekonomik kurumların, insan ilişkilerinin, düşünce ve zihniyet kalıplarının Türk toplumunda da yaratılması hedeflenmiştir. Burada amacımız Türk toplumunun modernleşme sürecinin tarihini ayrıntılı olarak ve bütün görünümlerinde ele almak değildir; amacımız bu sürecin temel özelliklerine değinerek bu süreçte pozitivizmin, daha doğrusu pozitivist sosyolojinin nasıl bir rol oynadığını ortaya koymaktır. Konuyu ele aldığımızda göreceğimiz gibi, Türk toplumunun modernleşmesi/modernleştirilmesi çabasında, bir toplum ve siyaset tasavvuru olarak, bir dünya görüşü olarak, bir zihniyet modeli olarak pozitivist düşünce başlangıçlarından itibaren bu sürecin aktörlerinin neredeyse tümünün geliştirdikleri toplum ve siyaset projelerinin arka planını belirlemiştir.

Modernleşme çabalarının Osmanlı'da III. Selim, II. Ahmet döneminde başladığı öne sürülmektedir (Berkes 1978). Bu dönemdeki modernleşme 'nötr' ve 'teknolojiyle sınırlı'dır, dolay1s1yla belki de modernleşmenin sorunsuz bir biçimde kabul gördüğü dönemdir (Kahraman 2002, 125). Ancak genel olarak, sürecin bütünü düşünüldügünde modernleşmenin ya da Batıl1laşmanın esasen siyasal bir içerik kazandığı ve sadece teknolojik bir gelişmeyi değil, zihniyet, kurum ve kimlik düzeyinde de bir dönüşümü gerektirdiği görülmektedir. Sürecin siyasal bir içerik kazanması ve aynı zamanda kültürel normlar ve değerler dünyasında da değişimi gerektirmesi, kendi muhaliflerini de yaratmıştır. Bu yüzden modernleşme süreci sorunsuz ve toplumun bütün öncü aydınları tarafından benimsenmiş bir biçimde ve düz bir çizgide ilerlemez. "Elit tabakanın düşünce ve güdüleri düzeyinde bile Türk modernleşmesinin izlediği yolu modernleşme literatürünün kesin ve tek yanlı kategorilerine slğdırmak epeyi zordur. Elit düzeyinin ötesine geçerek Osmanlı/Türk modernleşmesinin toplumsal dayanakların incelediğimizde, genel tablo büsbütün karmaşık bir hale gelmektedir" (Kasaba 1998, 18). Modernleşme sürecinin siyasal bir içerik kazanması Tanzimat Fermanı'nın ilânından itibarendir. Dolayısıyla bir zihniyet ve normlar değişimini ifade etmesi anlamında modernleşme ya da Batılllaşma esasen Tanzimat döneminde başlamış ve Cumhuriyetle birlikte 'bütüncü' bir karakter kazanmıştır. Modern bir düşünce geleneği olan pozitivizmin Osmanl1-Türk düşünce dünyasına girişi de doğal olarak modernleşme süreciyle eşzamanlı olmuştur ve modernleşme sürecinin seyrine uygun olarak; başlangıçta bilimi ve teknolojik ilerlemeyi mümkün kılan epistemolojik çerçeve, modern toplumsal siyasal kurumların meşruiyet zemini ve nihayet 'topyekün' Batılı ve seküler bir toplum ve siyaset modelinin ideolojisi olarak algılanmıştır. Her sınıflandırma veya dönemleştirmenin kuşatıcı olmadığının, kimi ayrıntıları göz ardı ettiğinin ve aynı zamanda, bir ölçüde söz konusu sınıflamayı yapanın öznel tercihini de yansıttığının farkında olarak Türk modernleşmesi, pozitivizm ve sosyoloji ilişkisinin bu çerçevede değerlendirilebileceğini düşünmekteyiz.

\section{Modernleşmenin Başlangıcı}

Osmanlı İmparatorluğu'nun kuruluşu ve yükselişi, Batıda Ortaçağın ekonomik, siyasal ve düşünsel planda çözüldüğü ve yerini yenilerine bıraktığı döneme tekabül etmektedir. 13. ve 14. yüzyıldan itibaren Batıda çok önemli değişimlerin ilk işaretlerini oluşturan Rönesans hareketi düşünce ve zihniyet planında Hıristiyanlığın ve skolastik felsefenin dogmatik düşünüş biçiminden kurtulup Hellen akılcılı̆̆ına dönme isteğini dile getirmekteydi. Onu hemen izleyen Reform hareketi yükselen burjuva sınıfının din-devlet ilişkilerinin yeniden düzenlenmesi gerektiği talebini yansıtmaktaydı. Pazar ekonomisinin doğuşu ve kapitalist üretim biçiminin hâkim hale gelişi Batıda ulus-devlet tarzı merkezi örgütlenme modelini gündeme getirmişti. İngiliz Devrimi söz konusu bu gelişmeleri siyasal düzlemde yansıtan önemli bir değişime işaret etmekteydi. 17. yüzyılda gerçekleşen 'bilimsel devrim' sadece entelektüel açıdan ve düşünce dünyasında bir değişimi değil, aynı zamanda Batının bugünkü 'üstünlüğünün' en önemli kaynağını oluşturan Sanayi Devriminin motor gücü olan teknolojik gelişmeyi mümkün kılan bir değişimi de 
içermekteydi. 18. yüzyılda yükselen Aydınlanma hareketi ise evrensel bir 'akıl' kavramı çerçevesinde 'eski'nin bütün değerlerinden kopuşun en kesin ve en keskin formunu oluşturmaktaydı. Nitekim Aydınlanmacı zihniyetin siyasal ifadesi olan Fransız Devrimi eşitlik, özgürlük ve kardeşlik ilkesiyle 'eski rejimi' yerle bir ederken, bu yeni değerlerin 'insanlığın ortak değerleri' olduğu ve artık Batının bir uygarlık olarak bütün insanlık için evrensel bir model oluşturduğu iddiasına kaynaklık etmekteydi. Batıda bu sözünü ettiğimiz ekonomik, siyasal ve zihinsel değişimler ve devrimler yaşanırken Osmanlı İmparatorluğu kendi varoluş ideolojisiyle, kendi kurumları ve idari yapısıyla kendi içinde göreli bir istikrara sahipti ve dolayısıyla Batıdaki bu gelişmelere karşı büyük ölçüde kayıtsızdı. Kazanmış olduğu askeri zaferler ve bunun sonucunda coğrafi sınırlarının ulaştığı genişlik düşünüldüğünde imparatorluğun Batıya karşı sadece kayıtsız olmadığ sahip olduğu bile söylenebilir. Ancak, hem yukarıda sözünü ettiğimiz gelişmelerden ötürü Batının gerçekleştirdiği teknolojik devrim ve bunun sonucunda ulaştı̆̆ 1 ekonomik refah, hem Fransız Devrimi'nden sonra bütün dünyaya hâkim olan milliyetçilik dalgasının imparatorluk içinde yarattığı hareketlilik ve hem de İmparatorluğun art arda uğradığı askeri bozgunlar imparatorluğu eski kendi kendine yeten istikrarlı düzeninde sürdürmeyi imkânsız kılmıştı. İmparatorluğun gerilemesi yönetici kadrolardaki Batıya karşı hâkim olan duyguyu da değiştirmişti: Öncekinin aksine, Batı karşısında sahip olunan duygu deyim yerindeyse bir 'eziklik' duygusuydu. Yönetici kadrolar, askeri ve idari bürokrasi İmparatorluğun yaşatılması ve yeniden kendi düzenini sürdürebilmesi için çözümler aramaktaydılar. Söz konusu kadrolarda giderek etkili olan çözüm önerisi ‘Batıya benzemek' olarak tanımlanmaktaydı. N. Mert'in $(1993,17)$ de ifade ettiği gibi, "sorunlarımıza çözüm arama süreci aynı zamanda toplumumuzda Batılılaşma sürecidir, zira sorunumuz Batıdan farklı olmak olarak tespit edilmiş ve çaresi de giderek daha yaygın bir şekilde ona benzemeye çalışmak olarak kabul edilmiştir".

Osmanlı'da modernleşmenin ne zaman başladığı konusunda kesin bir tarih vermek her ne kadar güç ise de (Ortaylı 1983, 10), modernleşmenin ilk aşaması Batının tekniklerinden yararlanmanın ve Batının tekniğinin ithalinin ifadesi olan Mühendishanenin kurulmasıly sembolize edilir. Gerçi Mühendishanenin kurulmasından epey bir zaman önce de özellikle savaş araçgereçleri konusunda imparatorluk, Batının tekniğini ithal etmekte ve ondan yararlanmaktaydı (İhsanoğlu 1991, 85-124). Ancak Mühendishanenin kuruluşu söz konusu yararlanmayı, deyim yerindeyse bir 'zihniyet etkilenmesi'ne dönüştürmek bakımından önem ifade etmektedir. Mühendishanenin kurulmasının ardından, daha sonra Tanzimat döneminin etkin aydınlarının çoğunun mensubu olduğu Tibbiye kurulmuştur. N. Berkes'in ifade ettiği gibi Aydınlanma dönemi düşüncesinin ilk yansımaları Tıbbiyede başlamıştır (Berkes 1978, 180). Eğitim dili bizzat padişah II. Mahmut tarafindan Fransızca olduğu beyan edilen bu okul, bir bakıma, Fransız pozitivizminin ithalinde öncülük eden simalarla doludur. Bu konuya aşağıda yeniden değineceğiz, ancak burada şunu belirtmemiz gerekir ki, pozitivizmin Türkiye'ye meslekten sosyolog veya siyaset bilimci olmayan tıbbiyeliler tarafindan sokulması, onun, hastalıklı bir toplumun tedavisinin yegâne bilimsel ve zorunlu metodu olarak algılanmasına yol açmıştır ve nitekim bu algıdır ki pozitivizmi 'hastalıklı' İmparatorluğun kurtarıcı can simidi haline getirmiştir.

Mühendishane ve Tibbiyenin kuruluşunu Harbiye'nin kuruluşu izlemiştir. Berkes'e göre Harbiye'nin kuruluşu “çağdaşlaşma tarihinin belki de en önemli olayı"dır (Berkes 1978, 191). Bu okul daha sonra gerçekleştirilecek birçok reforma bir bakıma öncülük etmiştir. Öğretmenlerinin çoğu Mühendishanenin mezunlarından olan Harbiye Türk tarihinde, sadece askeri bilgilerin ve tekniklerin öğretildiği bir yer olmaktan öte bir anlam ifade etmektedir. Tanzimat döneminde yerleşik bir kurum haline gelen Harbiye, Berkes'in ifadeleriyle "bazen kurulu düzenin, bazen reformculuğun, hatta devrimciliğin dayanağı olmuştur. Bu da yönetenlerin onları sadık hale getirebilme derecesine bağlı olmuştur" (Berkes 1978, 190). 
Batının üstünlüğünün sadece bilimsel ve teknolojik gelişmişliğinden kaynaklandığı görüşü başlangıçta yönetici kadrolara hâkim olan bir görüştü. Bu yüzden kültürel, kurumsal ve değerler dünyası bakımından 'nötr' olduğu düşüncesiyle Batının bilim ve tekniğini ithal etmekle İmparatorluğun hem özgül değerlerinin ve kurumlarının korunabileceği hem de yeniden güç kazanacağı düşünülmüştü. Ancak Batıyla temasın bir şekilde başlaması Batının 'ileri' bir medeniyet olmasının sadece bilim ve teknolojideki üstünlüğüne dayanmadığı, kendi tarihi içerisinde gerçekleştirdiği bir dizi ekonomik ve siyasal değişimin de söz konusu ilerlemenin önemli faktörlerini oluşturduğunu gözler önüne sermiştir. Yukarıda da değindiğimiz gibi, Osmanlı'da modernleşme çok kısa bir süre içerisinde 'siyasal' içerik kazanmış ve modernleşme çabaları deyim yerindeyse öncelikle siyasal bir çerçevede sürdürülmüştür. Pozitivizmin esasen, Türk modernleşmesinin siyasal bir içerik kazandığı aşamadan itibaren, dönemin aydın bürokratları, yönetici elitleri arasında etkin olan bir düşünce geleneği haline geldiği söylenebilir. Dönemin siyasal sorunları devlet görevlisi elit-aydını, Batının siyasal kurumlarını incelemeye yöneltmiştir. Bu süreç doğal olarak, onların dönemin Avrupa'sında hâkim olan toplum ve siyaset öğretileriyle tanışmalarına vesile olmuştur. Genel olarak modernleşmenin başlangıcına ilişkin bir tarih belirlemenin güç olduğunu belirtmiştik, ancak modernleşmenin siyasal boyutta bir ivme kazanmasının tarihi bellidir: Tanzimat Fermanı'nın ilânı. Bilindiği gibi Tanzimat'ın ilânı Osmanlı'nın siyasal anlamda Batıya kapılarını açtığı ana işaret etmektedir ve bu tarihten itibaren Türk toplumunun modernleşmesi ya da Batılılaşması kesintisiz bir biçimde sürmüştür. Kuşkusuz Tanzimat dönemi birçok bakımdan ele alınabilir ancak burada modernleşme projesi bak1mından Tanzimat'ın genel özelliklerine değinerek modernleşme sürecinin daha sonraki aşamalarına devrettikleri üzerinde durup, asıl ilgimizi bu süreçte pozitivizmin Osmanlı'ya girişi ve ilk etkileri üzerinde yoğunlaştıracağız.

\section{Tanzimat: Siyasal Bir Proje Olarak Modernleşme ve Pozitivizmin Osmanlı'daki İlk Etkileri}

Tanzimat dönemi, Osmanl1-Türk tarihinde üzerinde en çok tartışma yapılan dönemdir (Güngör 1982, 18-25). Ortaylı'nın ifadesiyle Tanzimat “devirden devire siyasal atmosfere göre değişik yorumlara konu olmuştur. 1930’ların Cumhuriyetçileri, Tanzimatçılar yüzyıl önceki saygıdeğer öncüler olarak değerlendirmişlerdir. 1960'ların siyasal sorunları içinde Tanzimat devrine bakan aydınlar ise Tanzimat reformlarının yapısını ve Tanzimatçıların dünya görüşünü Türkiye'nin ekonomik çıkmazının ve bağımlılı̆̆ının tarihi sorumluları olarak göstermişlerdir" (Ortaylı 1983, 13). Ancak değerlendirmeler ne olursa olsun şurası muhakkaktır ki, Tanzimat'in modern Türkiye'nin oluşumundaki payı büyüktür ve bu bakımdan gerçekten de, Osmanl1-Türk tarihinde bir dönüm noktasıdır.

18. yüzyıldan itibaren İmparatorluğun ekonomik yapısı Avrupa'nın geçirmekte olduğu dönüşüme ayak uyduramamaktaydı. Batıyla yürütülen ekonomik ilişkiler eşitsiz bir mübadele ilişkisine dayanmaktaydı ve bundan ötürü kimi ülkelere çeşitli imtiyazlar verilmişti. Siyasal örgütlenmesinde yer verdiği 'millet sistemi'gayri-Müslim azınlıklara kültürlerini koruma ve sürdürme olanağı sağlamaktaydı. Fakat Fransız Devrim'inden sonra dünyaya yayılan çeşitli fikirler içerisinde özellikle milliyetçilik, gayri-Müslim milletler arasında etkili olmaya başlamış ve imparatorluk içinde milliyetçilik merkezli tepkiler ortaya çıkmıştı. Yönetici kadrolar imparatorluk içindeki karmaşayı bertaraf etmek ve merkezî iktidarı güçlendirmek adına çeşitli önlemler alma ihtiyacı duymaktaydılar. İşte bu amaçla Sultan Abdülmecid'in izniyle Mustafa Reşit Paşa tarafından Gülhane parkında okunan ve Gülhane Hattı Hümayunu olarak anılan Tanzimat Fermanı bir dizi siyasi ve hukuki reformun gerçekleştirileceğini ilân etmekteydi. Fermanda gerçekleştirileceği beyan edilen en önemli husus, ırk ve milliyetine bakılmaksızın bütün vatandaşlara eşit haklar tanınacağının, herkesin can ve mal güvenliğinin teminat altına alınacağının vaat edilmesiydi. Tanzimat'ın getirdiği yeniliğin, Tanör'e dayanarak, esasen iki kavram altında ifade edilebileceğini söyleyebiliriz: Yeni yönetim usulleri ve hak ve dokunul- 
mazlıklar (Tanör 2000, 87). Yeni yönetim usulleri için vurgulanabilecek şey iktidarın kendi kendisini sınırlandıracağını taahhüt etmesidir. Yasalar, yasaları yapan ve uygulayanlar da dâhil olmak üzere herkesi bağlayacaktır. Hak ve dokunulmazlıklar açısından vurgulanabilecek en önemli şey ise kişi dokunulmazlığı ve güvenliğinin hukuksal olarak tesis edilmesidir. "Böylece kanunsuz suç ve ceza olamaz, yargılanmadan kimseye ceza verilemez ilkesi benimsenmiş oluyordu. Padişah da örfi ceza verme yetkisinden vazgeçiyor, bunları mahkemelere bırakıyordu" (Tanör 2000, 89).

Açıktır ki, bu ilkeler iktidarın mutlak olarak tek bir şahısta toplandığı, suç ve ceza kavramının geleneksel ahlâki ve dini değerlere göre tanımlandığı bir toplumda son derece önemli siyasal ve hukuksal değişimin işaretlerini vermektedir. Ancak hemen belirtmeliyiz ki Tanzimat'ın reformları sadece siyasal ve hukuksal alanla sınırlı kalmamıştır. Bunları, eğitim kurumlarındaki reformlar izlemiştir. Örneğin medreseler gerilemeye ve giderek önemini kaybetmeye başlamıştır. Modern eğitim kurumlarının yanı sıra kimi yabancı okulların da Tanzimat'tan hemen sonra açıldığını bilmekteyiz (Berkes 1978, 225-240; Ülken 1998, 49-56). Bu, düşünce dünyası bak1mından Batıya açılmayı ve Batılı fikirlerle daha kolay bir biçimde temas kurmayı sağlamıştır. Çünkü yine bilmekteyiz ki, birçok Batılı edebî ve bilimsel eser modern eğitim kurumlarında okutulmak üzere çevrilmiş ve daha sonra çeşitli hareketlere öncülük eden elit-aydının zihniyet dünyasının biçimlenmesinde belli bir etki yaratmıştır.

Yukarıdan ve devlet otoritesiyle gerçekleştirilen bu değişimlerin, Batıdan farklı olarak, ne ekonomik ve sosyal zemini vardı ve dolayısıyla yükselmiş toplumsal muhalefetin taleplerine bir yanıttı ne de söz konusu değişimlerin entelektüel- zihinsel bir arka plânı vardı. Bu vesileyle belki daha baştan burada vurgulamamız gerekir ki, Osmanl1-Türk modernleşmesi bütün aşamalarında yukarıdan ve devlet eliyle, devlete tâbi elit aydınların çabasıyla gerçekleştirilmiştir. Dolayısıyla birçok yenilik hemen kabul görmediği gibi, bir ölçüde tepkiyle de karşılanmıştır. İkinci olarak, bütün modernleşme çabalarına ve sürecine hâkim olan motif devletin korunup kollanmasının ve giderek daha güçlü bir hale gelmesinin sağlanmasıdır.

Batıdan ithal edilen fikirlerin taşıyıcıları veya ilk temsilcileri devlet görevlisi aydın bürokratlardır, dolayısıyla aktarılan bütün fikirler bir bakıma devletin kontrolünden geçmektedir. Ancak şurası da bir gerçektir ki, Tanzimat'la birlikte artık ok yaydan çıkmıştır (Ülken 1998, 40). Bu yüzden, Tanzimat, devletin kontrolünden çıkmasa bile bütünüyle devletin kontrolünde de olmayan bir düşünsel hareketlilik de yaratmıştır. Örneğin, Ülken'in ifade ettiği gibi, "Tanzimat yeniyle eskiyi, Avrupacılıkla İslâmcıll̆̆̆ karşı karşıya koyarken, medrese dlşına çıkmamış olan İslâmî ilimlerin Türkçeleşmesi veya yayılmasını să̆ladı̆̆ için Avrupacılık kadar İslâmcllı̆̆ın da kuvvetlenmesine hizmet" etmişti (Ülken 1998, 49). 19. yüzyıl Osmanlı düşünce dünyasına bakıldığında daha önce hiç olmadığı kadar farklı fikir hareketlerinin yeşerdiğini görmekteyiz (Mardin 1985, 342-351). Bu yüzyılda ortaya çıkan fikir hareketlerinin ortak paydası pratik bir kaygıya dayanmaktadır: İmparatorluğun karşı karşıya kaldığı sorunları çözmek ve İmparatorluğu kurtarmak. Dolayısıyla, yeri geldiğinde daha geniş bir biçimde ele alacağız ama burada ifade etmemiz gerekir ki, cereyan eden fikir tartışmaları Batıda olduğu gibi felsefi ve kültürel bir arka plâna sahip değildi. Bu yüzden Batıyla fikirsel ilişkiler bile aslında hep pratik bir içeriğe sahip olmuştur (Toker \& Tekin 2002, 82).

İster bir resmî görevle veya eğitim amacıyla olsun veya ister sürgün edilmiş olsun Avrupa'da bulunan 19. yüzyıl Osmanlı aydınlarının ve devlet adamlarının ortak bir özelliği vard1: Batı kentlerini gözlemlemek ve gözleme dayalı karşılaştırmalar yapmak. "Kent ölçeği içinde gözlemlenen tüm öğeler, yapısal bir bütüne katılan ve ona canlı bir organizma karakteri veren organlar olarak kavranmaya başlandl. Artık sorun bu canlı varlığın ruhunu araştırmaktı $k i$, bu da düşünsel alanda modern bir toplumun hangi felsefe sistemine dayandiğına cevap bulmaktan başka bir anlam taşımıyordu" (Işın 2002, 354). Osmanlı aydınları Batıyla temasa 
geçtiklerinde ve sözkonusu sistemin felsefi kaynaklarını merak ettiklerinde Batı uygarlığının ne felsefî olarak ne de siyasal ve kültürel olarak homojen bir yapıya sahip olmadığının farkındaydılar. Örneğin bu dönemde Batıda felsefi olarak ampirist-duyumcu, siyasal olarak liberal bireyci olan Anglo-Sakson geleneği, Alman idealist geleneği ve nihayet toplumcu Fransız pozitivist geleneği vardı. Osmanlı aydınının tercihini Fransız pozitivizminden yana yaptığı tarihi bir gerçektir. Kuşkusuz tercihin Fransız pozitivizminden yana yapılmasının, iki ülke arasındaki somut ilişkilerden ötürü bir bakıma kaçınılmaz olduğu da bir gerçektir. Ancak hemen belirtilmelidir ki, 19. yüzyı1 Fransız pozitivizmi, tam da Osmanlı aydınının ihtiyaç duyduğu yenilikleri yapmanın ve aynı zamanda toplumsal istikrarı korumanın programını barındırmaktaydı. Çünkü Fransız pozitivizmi "modernleşmenin hedeflerini ve araçlarını aydınlarımıza kavratabilecek pratik bir yapıya sahipti... Toplumun somut koşullarını temel alan pratik kavramsallaştırmaya önem vermesi ve bu kavramsal yapının merkezine spekülâtif bilgiyi değil bilimin pozitif felsefesini yerleştirmesi bakımından modernleşme çabalarında eksikliği duyulan düşünsel dayanak noktalarını Osmanlı aydınına kazandırmıştı" (Ișın 2002, 343-344). Pozitivizm hem bilimseldi, bu açıdan değerler-üstü bir şekilde kabul edilebilirdi, hem de bu vasfiyla bir toplum projesi gerçekleștirme imkânı sunmaktaydı. Dolayısıyla bu perspektiften, toplumun yapısını bilimsel olarak tespit etmek, sorunlarını bilimsel olarak teşhis etmek ve bilimsel olarak toplumu örgütlemek için gerekli yöntemi bilmek mümkün olabilecekti.

Pozitivizmin Osmanlı'ya girişi doğrudan felsefî̀ bir etkilenme ve doğrudan felsefi kanallarla değildir (Korlaelçi 1986; Korlaelçi 2002, 214-222). Başlangıçta çeşitli edebiyat akımları vasıtasıyla ve yukarıda sözünü ettiğimiz modern eğitim kurumlarında okutulan pozitif bilim dersleri sayesinde pozitivizm tanınmaya başlamıştır. Tanzimat döneminde kendisinden etkilenilen pozitivizm genel olarak Aydınlanma ruhu çerçevesinde geliştirilen toplum ve siyaset felsefelerinde belirginleşen anlamda pozitivizmdir. "Tanzimatçı düşünce siyasi görüslerinde 18. yüzyılın Aydınlanma görüşünü benimsemeye çalışmış, bu yüzyılın devlet felsefesine ait olan 'Espirit des Lois ve 'Contract Social' gibi başlıca eserlerin başlıca siyasi görüşlerini, her ne kadar sistemli bir biçimde değilse de, gene de ana hatlart ile gazete ve dergilerde 'fragmentler' halinde parça parça memleketimize aktarmaya girişmişlerdir" (Birand 1998, 6).

Şinasi (1826-1871), Münif Paşa (1828-1894) ve Ali Suavi (1839-1878) bu anlamda pozitivizmin Osmanlı'daki ilk simaları olarak kabul edilebilir. Tanzimat Fermanını okuyan Reşit Paşa'nın himayesinde yetişen Şinasi, Batı medeniyetinin kurucu felsefî öğesinin ne olduğu sorgulamasında, söz konusu medeniyetin esasen akıl ve yasaya dayandığı yargısına varmıştır (Ülken 1998, 66; Işın 2002, 355). Şinasi'ye göre çağdaş uygarlığın yönetici gücü olan akı1 dinamik bir yapıya sahiptir ve bu dinamizme uygun olarak Batı uygarlığı da sürekli olarak gelişmekte ve ilerlemektedir. Bu görüşleri çerçevesinde Şinasi, Osmanlı toplumunu akıl kavramı çerçevesinde sorgulamaya başlayan ilk aydındır (Işın 2002, 355). Yasa ise, ona göre, soyut olan adaletin somutluk kazanmasını ifade etmektedir ve Batının gerçekleştirdiği en önemli değişimlerden biri de budur. İşte Osmanlı idaresinin zaten Tanzimat'la yapmaya çalıştı̆̆ budur: Toplumu akılsal olarak düzenlemek ve yasayı tesis ederek toplumda huzursuzlukları gidermek. Bu yeni medeniyet Şinasi'ye göre aslında İslâm'ın temel prensipleriyle çelişmemektedir. Tam tersine İslâm zaten baştan itibaren bu değerlere sahiptir, ancak basiretsizlik yüzünden bu değerler zamanla ihmal edilmiştir. Ülken'in ifade ettiği gibi Şinasi'de, daha sonra yükselecek olan hürriyet talebini güçlü bir biçimde dile getirmez. "O hiçbir rejim değişikliği istemez. Tarafsız bir hükümdar yerinde kalmalıdır... Osmanl birliğinin şimdiki görevi dedelerimizin kurduğu bu devleti korumaktır" (Işın 2002, 355).

Şinasi'de görülen bu ikilik, yani bir yandan Batının bilimsel zihniyetine, kurumlarına ve uygarlık başarılarına yapılan övgü ile kendi dinsel değerlerine sadakat, Cumhuriyete kadarki bütün modernleşme süreci boyunca varlığını sürdürecektir. Örneğin bir yandan Batı tarzı yasalar 
uygulanırken bir yandan da şeriat yasalarının varlığı devam etmiştir; bir yandan modern eğitim kurumları açılırken diğer yandan medreseler de birer eğitim kurumu olarak varlıklarını sürdürmüşlerdir. Yukarıda da ifade ettiğimiz gibi, modernleşmenin bütüncü bir karakter kazandığı Cumhuriyet döneminden itibaren kurumsal düzeyde ikilik kaldırılmıștır. Ancak 19. yüzyılda, Batıyla ilişkkilerin başladığı ve geliştiği andan itibaren Batı-Doğu/İslam sorunu kültürel ve ideolojik çerçevede canlı bir tartışma konusu olarak günümüze kadar hep var olagelmiştir. Yeri geldiğinde bu konuya aşağıda yeniden değineceğiz; fakat burada da hemen ifade etmek gerekir ki Batı-dışı toplumların modernleşme sürecinin ikilik çizgisinde ilerlemesi kaçınılmazdır. Çünkü Batı-dışı toplumların modernleşmesi yukarıdan, deyim yerindeyse toplumun bünyesinin dışından bir müdahaleyle gerçekleştirilmektedir. Dolayısıyla modernleşmeyle birlikte getirilen değişimlerin kısa sürede ve tepkisiz olarak kabul görmesi mümkün değildir.

Kuşkusuz burada Tanzimat dönemi düşünürlerinin görüşlerini ayrıntılı olarak ortaya koymamız gereksizdir. Dikkat çekici olması bakımından Münif Paşa ve Ali Suavi'nin bazı görüşlerine burada kısaca değinmemiz yeterli olacaktır. Münif Paşa 18. yüzyıl ansiklopedistlerinin yaptığına benzer bir şeyi Osmanlı'da yapmaya çalışmıştır. Dönemin tartışmalarında 'bilimci' bir tutum takınan Münif Paşa, Ülken'e göre "evrimci ve terakkici bir medeniyet ögreticisi"dir (Ülken 1998, 68). Ali Suavi ise ilk defa açık bir biçimde lâiklikten söz etmesi bakımından dikkat çeken bir konumdadır. Ali Suavi'ye göre dünyanın kendine özgü yönetim yasaları vardır dolayısıyla dünya, dinî yasalarla yönetilemez. Din ve devlet işlerinin birbirinden ayrılması gerektiğini vurgulayan Suavi "ilm-i siyasetin esast şeriat ve edebiyat değil, coğrafya, iktisat ve ahlâk olduğunu söylüyordu" (Ülken 1998, 79). Ayrıca Ali Suavi'nin, Le Play'in Doğu-Batı toplumlarını değerlendirirken yaptığı 'communautaire ve particulariste' toplum tipi sınıflamasının farkında olduğunu da görmekteyiz (Ülken 1998, 80).

$\mathrm{Bu}$ görüşler Batılı birçok devlet ve toplum kuramının Osmanlı'da bir ölçüde artık yankı bulduğunun işaretleridir. Ancak esas yankılanmanın Tanzimat'tan sonraki dönemde, yani Tanzimat'ın etkilerinin çeşitli toplum kesimlerine yayılması sonucu bizzat Tanzimat'ın doğurduğu siyasal tartışmalarla başladığı söylenebilir. Tanzimat'ın getirdiklerinin gerçek anlamını bulması için Batılı siyasal kurumların Osmanlı'da inşa edilmesi gerektiği fikri, aydınları çok daha sistematik bir biçimde Batıya yönelemeye sevk etmiştir. Modern Türkiye'nin inşasında deyim yerineyse ideolojik harç işlevi gören 19. yüzyıl pozitivizmi de esas olarak, I. Meşrutiyetin başarısızlığının ardından sistematik olarak ithal edilmiş ve bir tür 'kurtarıcı' olarak görülmüştür.

\section{Meşrutiyete Kadar Modernleşme Süreci: Siyasal Bir İdeoloji Olarak Pozitivizm}

Yeni Osmanlılar hareketi bir bakıma, Tanzimat'ın Mustafa Reşit Paşa'dan sonraki uygulayıc1ları olan Ali ve Fuat Paşa'ya karşı bir hareket olarak biçimlenmiştir. Çünkü Tanzimat'a hâkim olan siyasi zihniyet, 18. yüzyılda Batıda hâkim olan kameralizmdi. Aydın despotizmi olarak tanımlanabilecek kameralizmin, doğası gereği halka geniş bir özgürlük vermesi söz konusu olamazdı (Mardin 1985, 343). Tanzimat' in getirmek istediği yenilikleri daha etkin hale getirmek için Ali ve Fuat paşa öncülügünde sürdürülen uygulamalar, kameralizmi pekiştirmekteydi. Bu uygulamalarda tebaya, halka daha geniş özgürlükler sağlamak gibi bir amaç güdülmemekteydi. Yeni Osmanlılara göre Tanzimatçı paşaların kavrayamadığı şey, Batının özgürlükçü ve parlamenter bir düzende bu ileri düzeyi yakalamış olduğudur. O halde eğer Osmanlı da ileri bir düzeye ulaşmak istiyorsa özgürlükleri artıracak ve genişletecek bir siyasi yapı tesis etmelidir.

Şinasi’nin görüşlerinden ilham alan ve bu hareketinin öncülerinden olan Namık Kemal, Ziya Paşa, Ali Suavi daha fazla 'hürriyet' talep etmekteydiler. Bu aydınlara göre Tanzimat ve arkasından gelen Islahat uygulamaları esasen Batının Osmanlı'daki imtiyazlı pozisyonunu arttırmış, dolayısıyla ekonomik emperyalizmi pekiştiren bir uygulamaya dönüşmüştür. Ayrıca Tanzimat'tan sonra, kültür planında Batının 'taklit' edilmesi, toplumu kendi bünyesine bütü- 
nüyle yabancı unsurların etkisiyle bozulma sürecine sokmuştur. Onlara göre Tanzimat'ın felsefi, siyasi ve kültürel zemini oluşturulamamıştır. Söz konusu zemin, basit bir Batı taklitçiliği ile zaten oluşturulamaz da. Bu boşluk ancak toplumun kendi kültür ve anlam dünyasına uygun düşen değerlerle doldurulabilir. "Yeni Osmanlılar bu boşluğu doldurmak için İslâm felsefesinden yararlanmayı teklif ediyorlardı. Onlara göre İslâm'da siyasal demokrasinin esaslarını bulmak da mümkündü' (Mardin 1985, 345). Böylece 'hürriyet' talebi de toplumun kendi değerler dünyasına uygun normlarla karşılanmış olabilecekti. Mardin'in tespitine göre bu söylemle din, imparatorluk içinde ilk defa bir 'ideolojik eksen' kazanmış olmaktaydı (Mardin 1985, 345).

19. yüzyılın gelişmeleri içinde Tanzimat'a tepki olarak belirmiş diğer bir hareket olan İslâmcılık hareketi Batıya muhalif olmak bakımından Yeni Osmanlılardan çok ileriye gider. Aslında Batının maddi kültüründen yararlanmayı savunmak ve 'terakkici' bir söyleme sahip olmak bakımından Yeni Osmanlıların bir anlamda 'Batıcı' bile oldukları söylenebilir. Esasen II. Meşrutiyet döneminde etkili olan İslâmcılık ise Osmanlının, Tanzimat'la birlikte başlattığı 'Batıya benzeme' çabasının bütün benliğini yitirmesine sebep olduğu, onun ancak 'şerait değerlerini' yeniden canlandırarak kurtulabileceği düşüncesine dayanmaktadır (Tunaya 1991). 1876 anayasasını ilga ederek I. Meşrutiyeti bastıracak olan II. Abdülhamit İslâmcıların bu görüşlerine sarılacaktır. O, İslâmcılık hareketinden esinlenerek geliştirdiği Pan İslâmizmi hem iç hem de dış politikada bir ilke olarak kullandı. Bir yandan Müslüman Osmanlı tebaayı İslâm bayrağı altında birleştirerek içeride gelişmekte olan milliyetçi akımları etkisizleştirmek istemekteydi, diğer yandan da bütün Müslüman ülkeleri halifelik makamı altında toplayarak 'birleşik Müslüman bir dünya' karşısında Batının ‘üstünlüğünü’ önemsizleştirmeyi amaçlamaktaydi.

Hiç kuşkusuz, 19. yüzyılın Osmanlı düşünce dünyasının en etkili ve en yaygın olan akımı 'Batıcılık' akımıdır. Bu akımla ilgili farklı hareket noktaları esas alınarak farklı tanımlamalar yapılabilir. Zaten hareketin kendisi de tek bir çizgide ilerlemiş homojen bir yapı sergilemez. Kendi kültürel değerlerini muhafaza ederek Batıyla 1lımlı bir ilişkiyi savunan da siyasal kurumlarını ve değerlerini radikal bir biçimde değiştirmeyi savunarak Batıyla ilişki kurmayı öneren de Batıcı olarak adlandırılabilmektedir (Mardin 1983, 245). Açıktır ki, Batıcılık kavramı aslında Batıyla bu sonuncu anlamda ilişkiyi savunana daha denk düşmektedir. Bu akımın modernleşmenin başlangıçlarından itibaren şekillendiği söylenebilir. Batılı fikirlerin sistemli bir biçimde Osmanlı'ya ithal edilmesi ve Osmanlı toplumu üzerinde Batılı düşünce gelenekleri aracılığıyla analizler yapma, I. Meşrutiyet döneminde II. Abdülhamit'e muhalif olan aydınlar tarafından gerçekleştirilmiştir. Bunun bir nedeni, yukarıda sözünü ettiğimiz Mühendishane ve özellikle Tıbbiye gibi okullarda okuyanların ve dolayısıyla dil bilenlerin artmasıysa, diğer bir önemli nedeni de, İmparatorluğun kurtarılması konusunda, Batının tek kurtarıcı model olduğu fikrinin aydınlarda giderek yerleşmiş olmasıdır. Sözünü ettiğimiz okullarda okutulan Batının pozitif bilimlerinin zihinlerde yarattığı etki, sadece bu bilimlere yönelik bir ilgiyle sinırlı kalmamış aynı zamanda bir Batı hayranlığına dönüşmüştür. Bu kuşağa göre bir uygarlık olarak Batının esas gücünün temeline pozitif bilim zihniyeti yatmaktadır: Pozitif bilim zihniyeti, doğa ve doğadaki olayları herhangi metafizik ya da doğa-üstü güce başvurmaksızın bizzat kendi içinde kavramak anlamına gelmektedir. Doğayı/dünyayı kendi içinde kavramak bir bakıma, onun üzerinde kontrol sağlamanın da mümkün olduğu anlamına gelmektedir. Batıda modern zamanların başlangıcından itibaren hâkim olan görüş budur. Kuşkusuz bu görüşün toplumun, insan hayatının kavranmasına ilişkin uzantıları olacaktır. Nitekim 19. Yüzyıl pozitif doğa bilimleri modelini örnek alan pozitif toplum ve insan bilimlerinin doğuşuna tanıklık etmektedir. Buna göre, doğa bilimleri modeline göre inşâ edilmiş insan ve toplum bilimlerinin amacı insanı, toplumu ve siyasal olayları, dışardan veya onun üstünde metafizik bir ilkeyle değil, bizzat kendi içinde kavramak ve bu yolla toplum üzerinde de kontrol sağlamaktı. İşte 19. yüzyılın sonlarına doğru Osmanlı aydınını en çok cezbetmiş olan şey, pozitif bilim zihniyetinin toplumsal, siyasal 
olayların kavranmasına olan etkileridir. Abdülhamit döneminin en önemli muhalif hareketi olan Jön Türk hareketinin önde gelenleri, Batının gücünün nereden geldiği sorusuna cevap verirlerken en çok vurguladıkları şey, Batıda toplumun ve siyasal olayların pozitif bilim kavramı çerçevesinde geliştirilen toplum bilimlerince kavranmış ve söz konusu bu bilimlerin verilerinden hareketle düzenlenmiş olduğuydu. O halde eğer bu pozitif bilim çerçevesinde hareket edilirse, İmparatorluğun gerilemesinin gerçek nedenleri teşhis edilebilir ve ardından gerekli önlemler alınabilirdi.

Jön Türkler'le birlikte İmparatorluğun mevcut idaresine karşı muhalefet ciddî bir siyasal boyut kazanmış ve fikir plânında çeşitli eğilimler birbirinden ayrılmıştır ve Batıcılık eğilimi daha açık bir biçimde belirmiştir. "Genç Osmanlılar hareketi 'ilerlemeci' ya da yeni düşünceleri kendi içinde billurlaştırır: Batıcıllk, Meşrutiyetçi Osmanlıcılık, entegrist olmayan reforumcu islâmcılık... Tüm bu eğilimler bu hareket içinde iç içe yer alır. Buna karşıllı bir sonraki kuşak olan Jön Türkler'de bu eğilimler gittikçe belirginlik kazanarak özerkleşirler ve birbirlerini dışlayan özerk hareketler haline gelirler" (Aktar 1993, 35). Birinci kuşak Tanzimat dönemi aydınlarının pozitivizmle ilişkisi, önce de ifade ettiğimiz gibi, daha çok pozitivizmin edebiyat akımlarındaki yansımaları olan realizm ve natüralizmden etkilenmeleri dolayısıylaydı. Jön Türk'lerle birlikte, pozitivizmin siyasal içerik kazanmış olan formu etkin olarak takip edilmeye başlandı. A. Comte'un pozitivizmi, 19. yüzyılın sonlarına doğru Osmanlı aydınını en çok çeken düşünce hareketiydi. Ahmet Rıza, 'siyasal pozitivizm'in, Comtecu pozitivizmin en önemli temsilcisidir (Özlem 2002, 452-464) ve bu bakımdan burada görüşlerine biraz daha fazla yer vermemiz gerekir.

Ahmet Rıza'nın pozitivizmle tanışması, Dr. Robine'nin 1887 yılında Comte üzerine yazdığ 1 bir kitabı okumasıyla başlar. Ancak pozitivizmden ciddi olarak etkilenmesi Paris'te bulunduğu yıllarda, Comte'un öğrencisi olan Pierre Lafitte ile ilişki kurmasından sonradır. II. Abdülhamit'e Paris'ten yazdığı layihalarda, toplumun ve siyasetin yasalarının bilimi olan pozitivizmi ona telkin eder: "Hükümeti idare etmek kumar oyunu gibi zarın talihine birakllamaz. Hakikatin halleri istiareye yatmakla bilinemez. Cemiyet tabii kanunlara bağll bir bileşik vücuttur". Comtecu pozitivizmde Ahmet Rıza'yı etkileyen şey tam da budur: Toplumsal, siyasal olaylar rastgele meydana gelmez, dolayısıyla toplum rastgele yönetilemez; toplum zorunlu yasalara bağlı olarak işleyen organik bir yapı arz eder. Toplumun zorunlu yasaları bilinip ona uygun olarak davranıldığında hem toplumun doğal düzeni korunmuş olur hem de toplum ilerletilebilir. Comtecu pozitivizmin bu ilkesi, yani düzen ve ilerleme (ordrè et porgrès) veya düzen içinde ilerleme Osmanlı yöneticilerinin ve aydınlarının en çok ihtiyaç duydukları şeydir: İmparatorluk hem ilerletilmelidir hem de mevcut yapısı muhafaza edilmelidir. II. Meşrutiyette etkili olan ve içinde Ahmet Rıza'nın da yer aldığı İttihat ve Terakki hareketinin adı bu Comtecu ilkenin Osmanlı'nın ihtiyacına göre ifade edilmiş şeklidir. Pierre Lafitte'in öncülüğünü ettiği derneğe katılan Ahmet Rıza, derneğin yayın organı olan Revue Occidentale'de yazdığı yazılarda, pozitivizmi kendi sorunu bağlamında daha sistematik bir çerçeveye oturtur. Daha sonra hem Fransızca hem de Türkçe yayınlayacağı Mechveret adlı dergide de Jön Türkler' in muhalif programının ilkelerini oluşturacak görüşlerini geliştirir.

Yukarıda da ifade ettiğimiz gibi, Ahmet Rıza'nın temel kaygısı İmparatorluğun bütünlük içinde tutularak Batının ulaştığı seviyeye ulaştırılmasının sağlanmasıdır. 19. yüzyılın siyasal reformları ve imparatorluk içinde ciddi bir parçalanmaya yol açabilecek milliyetçilik hareketleri, imparatorlukta tıpkı 1789 devrimi sonrası Fransa'sındaki anarşi durumuna benzer bir durum yaratmıştır. Devrim sonrası Fransa'sı koşullarında, bir toplumsal istikrar teorisi olarak, Comte tarafından geliştirilen Pozitif Politika kuramı Jön Türkler tarafından Osmanlı için de bir kurtuluş reçetesi olarak görülmekteydi. İki toplum arasında benzer olduğu düşünülen bunalımın benzer bir siyasal zihniyetle aşlabileceği düşüncesi Ahmet Rıza'yı pozitivizme yönelten en 
önemli motifti. Onun Osmanlı özgülünde geliştirdiği görüşlerinin genel çerçevesi Comte'un toplum ve siyaset kuramına dayanmaktadır. Bu yüzden burada çok kısa bir biçimde Comtcu kuramı hatırlamamız gerekli olacaktır.

Pozitif Felsefe Dersleri'nde Comte, devrimin Fransa'da yeni bir düzen inşa etmek yerine toplumun düzenini bozan bir etki yarattığını ifade eder. Şiddete dayalı devrimler toplumu ilerletmek yerine, onun ilerlemesi önündeki en önemli engelleri yaratmışlardır. $O$ halde yapılması gereken şey toplumun istikrar ve düzen içinde ilerlemesini bilimsel olarak sağlamaktır. "Comte'un amacı geleneksel otoritenin çerçevesinde ilerleme ülküsünü gerçeğe dönüştürebilecek yeni bir toplum düzeni yaratmaktır. Böyle bir düzene (ordrè) varabilmek için düşünsel anarşiye son verebilecek gücün pozitif bilimler olduğuna inanmıştı. Dolayısıyla bunalım içindeki bir toplumda düzen sağlandıktan sonra ilerleme (progrès) sağlanabilecekti” (Işı1n 2002, 357).

Comte insanlığın tarihsel birliğine inanmakta, insanlığın, tarihsel olarak teolojik, metafizik aşamaları geride bırakıp, gözlem ve deneye dayanarak olgular arasında nedensel ilişkiler kurarak düşünmek anlamına gelen pozitif aşamaya vardığını öne sürmektedir. Bu aşamada mutlak ve doğa-üstü nedenler yerine olgular arasındaki benzeşmelere ve ardışıklıklara dayalı nedenlerle düşünmek söz konusudur. Comte'a göre, her bir bilimin kendisi de özgül konusu bakımından bu aşamalardan geçerek pozitif bilim haline gelmiştir. "Bilgi diğer disiplinlerin genelliği ve bağımsızlı̆̆ına oranla pozitif aşamaya ulaşır. İlkin doğa bilimlerinin en geneli ve basit olan astronomi gelişir ve onu fizik, kimya, biyoloji ve sosyoloji izler... Sosyoloji, özellikle, hiyerarşideki önceli biyolojiye bağlldır" (Swingewood 1998, 63). Sosyolojinin biyolojiden sonra gelmesi hiç de tesadüfi değildir. Çünkü Comte'un tasavvurunda toplum tıpkı bir organizmadır. Nasıl ki canlı bir organizma her biri bir işleve sahip farklı organların birlikli bir bütünüyse, toplum da her biri farklı işlevi yerine getiren çeşitli öğelerden oluşan uyumlu bir bütündür. Canlı organizmadaki uyumsuzluk nasıl ki bir patolojiyse, toplumsal uyum ve düzenin bozulması da bir tür patolojidir ve pozitif toplum bilimine düşen görev toplumsal patolojinin olgusal nedenlerini tespit etmek ve bu patolojiyi gidermektir; kuşkusuz, daha sonra da, doğasına uygun düzenlemelerle toplumun ilerlemesini sağlamaktır. Bu yüzden sosyoloji ile biyoloji arasındaki yöntemsel benzerlik, sosyoloji ile diğer pozitif bilimler arasındaki benzerliklerden daha fazladır.

Comte pozitif sosyolojisini iki kısma ayırır: Toplumsal statik ve toplumsal dinamik. Toplumsal statik toplumun değişmeyen, toplumu oluşturan unsurların incelenmesidir, toplumsal dinamik ise toplumun ilerlemesi ile ilgili şeyleri konu edinir. Açıktır ki bu Comte'un düzen ve ilerleme ilkesine uygun bir bölümlemedir. Toplumsal statikle düzen korunurken toplumsal dinamikle düzen içindeki bir toplumun ilerlemesi sağlanacaktır. Bu yolla topluma ilişkin asli olanla tarihsel olan bilinebilecek ve dolayısıyla toplum kontrol altına alınabilecektir.

Comte'un bu görüşlerinin doğal sonucu, toplumun ancak topluma ilişkin 'bilimsel' bilgiye sahip olan elit aydınlar tarafından yönetilmesi gerektiğinin kaçınılmaz olduğudur. Nasıl ki her özel alanın bir bilimi ve bu bilimin uzmanı varsa, konusu toplum olan bir bilim ve toplumun işleyiş yasalarını keşfedecek olan uzman da vardır. Toplum söz konusu bilgiye sahip uzmanlar tarafından veya onların kılavuzluğunda yönetilirse toplumun düzen içinde ilerlemesi sağlanmış olur. Comte'un önerdiği bir tür toplum mühendisliğidir. Toplumun uzmanlar tarafından ve topluma ilişkin bilimsel-teknik bilgi aracılığıyla düzenlenmesi gerektiği görüşünü içeren toplum mühendisliği her ne kadar 19. yüzyıl Fransız pozitivizminde açık bir biçimde görülmekteyse de, bu görüş daha çok Batı-dışı toplumların modernleştirilmesi sürecinin aktörleri üzerinde etkili olmuştur. Bat1-dışı toplumlarda devletin üstten kararıyla toplumun modernleşme sürecine sokulması, doğal olarak bu süreçte elit bürokratları ön plana çıkarmıştır. Modernleşme sürecinde kendilerine etkin rol biçilen veya kendileri etkin rol üstlenen kesim elit bürokratlardır. 
Nitekim Ahmet Rıza'da bu görüşü çok açık bir biçimde izleyebilmekteyiz.

Ahmet Riza'da Comte'un görüşlerinin izlerini bire bir sürmek kuşkusuz mümkün değildir, çünkü Comte'un görüşleri ve eserlerinin onun tarafından özel bir incelemeye alındığının açık işaretleri yoktur. Onun Comte'dan etkilenmesi genel ve yöntemsel planda bir etkilenmedir (Fındıkoğlu 1962). Doğal olarak en açık etki, yukarıda da ifade ettiğimiz gibi, toplumun zorunlu yasaları olduğu, bu yasaların 'bilimsel' olarak bilinebileceği ve bu yasaların ancak uzmanlar tarafından keşfedilebileceği dolayısıyla siyasetin veya toplumu yönetme işinin uzmanlara bırakılması gerektiği konusundadır (Durakbaşa 1998, 98). Ahmet Rıza açısından en önemli mesele olan 'ilerleme', düşüncenin bilimselleşmesiyle mümkün olabilir. Modernleşme süreci çerçevesinde değerlendirirsek, bu süreçte Ahmet Rıza'nın hassasiyetle vurguladığ 1 şey eğitimin modernleştirilmesidir. Onun gözünde halk 'cahil bir kitle'dir ve sosyal olayların bilincinde olmayan halk, bozuk düzenin devam etmesinin de bir ölçüde sebebidir. Halkı kısa bir sürede eğiterek elit-aydının müttefiki haline getirmek pek kolay bir iş olmayacağına göre Ahmet Rıza için toplumu yönetme bürokrat elitin hakkıdır (Özden \& Lök 2001, 122). "Ona göre toplumu yeniden örgütleyen ve ilerlemesini sağlayan güç, rasyonel kurallar çerçevesinde düzenlenmiş bürokratik elitin denetimine verilmelidir" (Işın 2002, 359).

Ahmet Rıza'nın üzerinde durduğu meselelerden biri eğitimse diğeri de dindir. Aslında dini 'bilgi değeri' bakımından, bir başka ifadeyle epistemolojik olarak eleştiren Rıza, toplumsal yapının bütünlüğ̈̈ açısından gerekli bulmaktadır. Doğal olarak bu görüşün kaynağı da Comte'dur. Ahmet Rıza'ya göre dinin olumlu yönü, toplumu 'bütün' içinde tutabilme gücüne sahip olmasıdır. Pozitivist düşünce dinin yerini alıncaya kadar ondan vazgeçmeye imkân yoktur. Comte'un İnsanlığın Dini kavramının da Ahmet Riza üzerinde etkisi görülür. Comte'a göre bu yeni dinin 'rahipleri' uzmanlardır. Ahmet Rıza bu görüşü Osmanlıya uyarlar: Ona göre bu uzmanlık rolü askerlere verilmelidir. Askerlerin bilimsel eğitimleri, donanımları onları bu dinin rahipleri olmaya en elverişli kimseler kılmaktadır; onlar bu dinin en uygun 'havarileridir' (Aktar 1993, 127). Ahmet Rıza'nın bu görüşünün temelinde asker bürokratın Osmanlı'da önemli bir rol işgal ettiği olgusu vardır. Burada hemen Türk modernleşme süreci açısından şu saptamada bulunmak yersiz olmayacaktır: Modernleşme sürecinin elit-aydınları ya da başka bir ifadeyle mühendisleri baskın bir biçimde askeri bürokrasidir. "Rıza'nın düşüncesinde askerlerin önemli bir yeri vardır. Her şeyden önce çağdaş eğitimleriyle uyumlu olarak bir meslek ordusunun elemanlarıdırlar ve aydınlanmışların önemli bir bölümünü oluştururlar... Halkı ilerleme sürecine birlik içinde katmak ve onu sürekli ve genel bir seferberlik içinde tutabilir ve tutmalıdırlar" (Göle 1986, 54).

Kuşkusuz burada Jön Türk hareketinin bütün temsilcilerinin görüşleri üzerinde durmamız gereksizdir. Ancak şunu vurgulamalıyız ki, Jön Türkler, Osmanlı'da geçekleştirmek istediklerinin teorik çerçevesini büyük ölçüde Comtecu pozitivizmde bulmuşlardır. Jön Türklerin Avrupa'da bulundukları ve bir fikirsel arayış içinde oldukları dönemde Avrupa'nın en etkin düşünce geleneği Marksizm'di. Şunu görmekteyiz ki, Marksizm, Ahmet Rıza da dâhil Jön Türklerin ilgisini çekmemiştir. "Jön Türklerin Avrupa'da bulunduğu süre içinde çok daha yaygın olmasına rağmen Marx'ın düşüncesiyle hiç ilgilenmemeleri, başlıca kaygıları imparatorluklarını korumak olan ve bu nedenle düzeni her şeyin üzerinde gören bu reformcular açısından şaşırtıcı değildir" (Aktar 1993, 126). Toplumsal değişme ve ilerlemeyi devrimci bir formda gerçekleştirmekten kaçınan Jön Türklerin hedefi reformlarla bunu sağlamaktır ve 19 . yüzyıl muhafazakâr pozitivizmi bunu pekâlâ mümkün kılmaktadır.

Burada 19. yüzyıl pozitivizminin Osmanlı üzerindeki etkisini birkaç cümlede ifade etmek istersek, birinci olarak, onun siyasal ve kültürel alanın laikleştirilmesi sürecinde etkili olduğunu ifade etmemiz gerekir: Buna göre toplum ilâhî bir yaratım değil, insanî hayatın devamı için zorunlu olan ve kendine özgü yasalarla işleyen bir oluşumdur. Bunun doğal sonucu, siyasal 
yönetimin dünyevî bir şey olduğudur. Dolayısıyla onun insanî bilgiye dayanarak düzenlenmesi gerekir. Dinin toplumdaki yeri, toplumun bütünlüğünü sağlayan diğer herhangi bir kurumdan daha fazla ve daha önemli değildir. İkinci olarak, bürokrasinin rasyonel kurallara göre düzenlenmesi, elit-bürokrat kadronun devletçi ideolojiyi temel kabul etmesi pozitivist etkinin sonucudur. Ayrıca 'bilimselliğge' yaptığı vurguyla pozitivizm, genel olarak tüm toplumsal, siyasal ve kültürel meselelere 'bilimsel' bir perspektiften bakmanın epistemolojisi olmak bakımından, zihniyet dünyasının büyük ölçüde belirleyeni olmuştur. $\mathrm{Bu}$ da giderek hayatın bütünüyle sekülerleşmesi sonucunu doğurmuştur. Pozitivizmin bu etkileri Cumhuriyet döneminde de açık bir biçimde görülmektedir.

Pozitivizm sadece siyasal bir ideolojinin teorik zemini olarak Osmanlı düşünce dünyası üzerinde etkide bulunmamıştır ve 19. yüzyılda Osmanlı düşünce dünyasında etkili olan tek Batılı düşünce akımı hiç kuşkusuz Comtecu pozitivizm değildir. 18. ve 19. yüzyılın Batı dünyasının hâkim düşünce gelenekleri olan pozitivizm ve materyalizm Batıyla ilgilenen aydınlar üzerinde felsefi planda da etkili olmuştur. 19. yüzyılın sonlarına doğru ve özellikle II. Meşrutiyet sıralarında materyalizminin ciddi bir etki yarattığını görmekteyiz. II. Meşrutiyet döneminde sosyolojinin üniversitede ders programına girmesi farklı sosyoloji ekollerinin tanınmasını sağlamıştır. Bu bakımdan, II. Meşrutiyet dönemi, Osmanlı'da modernleşme süreci başladığından beri, en canlı düşünsel hareketliliğe ve tartışmalara tanıklık etmiş dönemdir. Kuşkusuz bu dönem Osmanl1-Türk modernleşme sürecinde siyasal bakımdan da önemli bir andır. Şimdi bu dönemin modernleşme sürecindeki siyasal önemine kısaca değinip, özellikle ona, yukarıda sözünü ettiğimiz düşünsel hareketlilik bakımından bir göz atmaya çalışalım.

\section{Meşrutiyet Dönemi Düşünce Hareketleri ve Türkiye'de Sosyoloji}

Meşruti monarşiyi tesis etmek üzere 1876' da yürürlüğe sokulan Kanun-i Esasi'nin bir y1l sonra Padişah II. Abdülhamit tarafından askıya alınması padişahın mutlak monarşisine karşı muhalif hareketlerin ortaya çıkmasına yol açtı. Jön Türk hareketi ve bir bakıma bu hareketten doğan Ittihat ve Terakki Cemiyeti bu muhalif hareketlerin en önemlileridir. Önce Ittihad-ı Osmani adıyla 1889 'da Askeri Tıbbiye'de gizli bir örgüt olarak kurulmuş olan cemiyet 1894'te adını İttihat ve Terakki olarak değiştirmiştir. Kurucuları arasında İbrahim Temo, Dr. Abdullah Cevdet, Ahmet Rıza gibi isimler olan İttihat ve Terakki'nin, 1908'de II. Meşrutiyetin ilanındaki etkisi kuşkusuz çok büyüktür. Özellikle bu örgütün bastırmasıyla padişah II. Abdülhamit Kanun-i Esasi'yi yeniden yürürlüğe sokmak zorunda kalmıştır. Kanun-i Esasi parlamenter sistemi getirmekte ve o zamana kadar hiç görülmedik ölçüde geniş özgürlükler sunmaktaydı. Jön Türk devrimi olarak da anılan II. Meşrutiyet, açıktır ki siyasal bakımdan çok büyük bir değişimi ifade etmektedir. Ancak, F. Ahmad'ın ifade ettiği gibi Jön Türkler "sadece siyasal sistemi değiştirmekle kalmadılar, eskisine kıyasla Batıdan daha çok şey alarak toplumu yeniden biçimlendirmeye çalıştılar" (Ahmad 1995, 51). II. Meşrutiyetle birlikte sadece siyasetin değil genel olarak 'hayatın modernleşmesi' sürecinin başladığını ifade etmek yersiz olamayacaktır. 'Bütün olarak' hayatın modernleşmesinin esasen Cumhuriyet dönemiyle başladığı bilinmektedir. Çünkü Cumhuriyetle birlikte toplumun geleneksel, kültürel kurumlarının tümü modern kurumlarla değiştirilmiştir ve değerler ve normlar dünyası yeniden inşâ edilmiştir. Ancak, bu sürecin en önemli uğrağının II. Meşrutiyet olduğu da tarihi bir gerçektir.

Yukarıda da ifade ettiğimiz gibi II. Meşrutiyet dönemi düşünce dünyası bakımından hareketli bir dönemdir. Daha doğrusu sadece hareketli değil aynı zamanda birbirlerine karşıt fikirlerin de mücadelesine tanıklık etmektedir. İmparatorluğun nasıl kurtarılabileceği tartışmalarında, sunulan çözümler sadece Batıcılık akımının sunduğu 'Batı modeli'nden ibaret değildir. İslâm'a veya Türk'lüğe vurgu yapan İslâmcılık ve milliyetçilik gibi akımlar da birer öneri sunmaktadırlar. Hiç kuşkusuz Batıcı akımlar milliyetçilikle rahatlıkla bir dirsek teması içinde olabilmişlerdir, ancak Batıcılık her halükârda İslâmcılıkla sürekli bir mücadele içinde olmuştur. II. Meşrutiyet dönemi bir bakıma, Osmanlı' daki değişim ve modernleşme sürecinin istikrarlı bir 
şekilde sürmesi için bu sürecin esas öznesinin ne olduğu veya ne olması gerektiği tartışmalarıyla geçmiştir. Osmanlıcılık, İslâmcılık ve Milliyetçilik bu tartışmaların sonucu ortaya çıkan akımlardır. Kuşkusuz bu farklı önerilerin dayandıkları farklı tarihi ve sosyolojik gerekçeler vardır. $\mathrm{Bu}$ konuyu burada ayrıntılı olarak işlememiz sorunumuz açısından gereksizdir. Ancak şu kadarını ifade etmemiz gerekir ki, söz konusu tartışmalar her ne kadar pratik kaygılardan doğmuşsa bile onların belli bir felsefî arka plânda yürütüldüğüne de tanık olmaktayız.

19. yüzyılın son çeyreğinden itibaren Osmanlı düşünce dünyasına baktığımızda, aynı zamanda, Osmanlı aydınları arasında felsefi diyebileceğimiz meselelere karşı da bir ilgi uyand1ğını görmekteyiz. Bu konuda ilk örneğin Ahmet Mithat olduğu öne sürülmektedir (Kaynardağ 1982, 73-90; Karakuş 1995, 73). Daha önce de belirttiğimiz gibi, Batılı fikir akımlarına ve Batıda tartışılan meselelere ilgi duyan aydınlar arasında Batı felsefesiyle ilgilenenlerin en çok materyalizmden etkilendiğini görmekteyiz. Bu şaşırtıcı değildir. Materyalizm, doğa bilimlerindeki gelişmeye paralel olarak özellikle 18. yüzyıldan itibaren Avrupa'da etkili olmaya başlamıştır. Osmanlı aydını üzerinde bilimin yarattığı etki düşünülürse, bilimin sonuçlarından hareketle veya bilime paralel olarak evreni, olayları açıklamaya çalışan bir felsefenin onlar üzerinde etkili olması son derece doğaldır. Bu anlamda materyalizm, din-dışı bir düşünce geleneği olmak bakımından Osmanlı aydınının ilgisini çekmiştir. "Osmanlı materyalizmi oldukça genişs bir tanım sinırı içinde kavranabilir. Dünyanın oluşumu ve insan varlığının teolojik açıklamasına karşılık, bilimsel verilerin ışı̆̆ında bir dünya ve insan tasarımı; gerçekliğin sezgiyle değil, akılla algılanabileceğini öngören bir düşünce açısı; hayatın manevi bir süreç olmayıp, maddesel değişimin deney yoluyla kavranabilir geçekliği olduğu ilkesi, Osmanlı materyalizminin tanımını kolaylaştıracak öğelerdir" (Işın 1985, 363). Açıktır ki materyalizmin bu özellikleri aynı zamanda pozitivizmin de özellikleridir ve ikisi arasında Batıcı Osmanlı aydının belirgin bir ayrım yaptığı söylenemez. Aralarındaki kimi farklara rağmen Batıcı aydınlar ya materyalist ya pozitivist ya da materyalist ve pozitivisttir (Hilav 1995, 360). Doğrusu etkilendikleri kaynaklar dikkate alındığında bu konuda ayrım yapabilmeleri pek kolay görünmemektedir. Her ikisi de ortak bir biçimde bilimin üstünlüğüne vurgu yapmaktadır; Osmanlı aydını için materyalizm en genel anlamada evrenin ve doğanın bilimsel açıklamasıdır, pozitivizm ise bu genel bilim zihniyetinin toplumsal meselelerdeki izdüşümüdür.

Osmanlı materyalizmi 18. yüzyıl aydınlanmacı Fransız ansiklopedistlerinin, Claud Bernard'ın fizyolojist akımının, Darwin'in evrim teorisinin ve Louis Büchner'in biyolojik materyalizminin izlerini sürdürür (Işı1n 1985, 363-364). Özellikle Büchner'in Madde ve Kuvvet adlı eseri Osmanlı'daki materyalist akımın biçimlenmesinde temel bir rol oynamıştır. Materyalizmle sistematik olarak ilgilenen ve dolayısıyla materyalizmin ilk temsilcisi kabul edilen Beşir Fuad'tır. O eserlerinde bir yandan öncelikle fizyoloji olmak üzere pozitivist bilimleri tanıtmaya çalışırken, diğer yandan da materyalist bir perspektifle sanat estetiği yapmaya çalışır (Korlaelçi 1986, 227 245). Beşir Fuad'a göre hakikat deneydedir ve deneyden gelmeyen her şey hayalden öte bir anlam ifade etmez. Buna dayanarak, filozof adına lâyık gördüğü Voltaire, Diderot, D’Alambert, De La Mettrie gibi 18. yüzyılın Aydınlanmacı ve ansiklopedistleri gibi isimlerdir. Doğal olarak felsefe olarak gördüğü şey de bizzat pozitif bilimlerdir. Onun bilime yaptığı vurgu, Ekrem Işın'ın ifade ettiği gibi, “kültürümüzde bir çeşit bilim kültü doğurmuş”tur (Işın 1985, 366). Açıktır ki bu güçlü bir metafizik karşıtlığının ifadesidir ve onun güçlü bir vurguyla ifade ettiği metafizik karşıtlığ özellikle Servet-i Fünun çevresinde etkili olmuştur (Karakuş 1995, 86).

Materyalist akımın tanınmasında öncülük etmiş olan diğer bir isim hiç şüphesiz Ahmet Şuayb'tır. Beşir Fuad'ta olduğu gibi onda da materyalizme yönelik ilgi edebiyat akımlarına duyduğu ilgi vesilesiyledir. Özellikle Fransız pozitivist edebiyat tarihçisi Hypolit Taine'den etkilenen Şuayb'ın tasavvurunda, felsefe genel bilimdir. Ona göre "insanlık için en sağlam ve en doğru yol olarak kabul edilen bilimi metafizik unsurlardan arındırmak felsefe ile mümkündür... 
Bu felsefe hikmet-i müsbete olarak adlandırllan pozitivizmden başkası değildir" (Karakuş 1995, 92). Metafizik baştan aşağı varsayımlar üzerine dayanır ve bir bilgi değeri yoktur. Ahmet Şuayb'ın A. Comte'a karşı büyük bir ilgi duyduğu kesindir. Ona göre Comte bilimin ve felsefenin sınırlarını en iyi bir biçimde belirlemiş ve insanlığı temel niteliliklerini en açık bir biçimde ortaya koymuştur.

Beşir Fuad ve Ahmet Şuayb’1 II. Meşrutiyet öncesinin düşünürleri olarak kabul edersek, II. Meşrutiyet'in en önemli materyalisti olarak Baha Tevfik' in adını anmamız gerekir. Baha Tevfik yukarda adını andığımız ve Osmanlı' da materyalist eğilimin güçlenmesine etkili olduğunu ifade ettiğimiz Lous Büchner'in Madde ve Kuvvet adlı eserini çevirmiştir. Onun çıkardığ Felsefe adlı dergi ilk felsefe dergisidir (Ülken 1998, 234). Felsefe, Baha Tevfik'e göre, insan aklının kendini ifade etme ihtiyacını en doğru biçimde karşılamayı mümkün kılan bir araçtır. Ona göre "din gayr-l ihtiyari bir felsefe, felsefe ihtiyari bir dindir" (Karakuş 1995, 118). Ancak kuşkusuz her felsefe söz konusu ihtiyacı doğru bir biçimde karşılamayabilir. 20 yüzyılda bilim ve felsefe arasında klâsik ayrımın kalktığını düşünen Baha Tevfik, bilimin bütün sonuçlarına açık olan materyalizmin güçlü bir felsefe olarak yüzyılın hâkim bilgi anlayışını yansıttığını düşünmektedir. Yazdığ 1 Felsefe-i Ferd adlı eserinde toplumsal hayatta bireyin rolüne vurgu yapar ve bireyin toplumda güçlendirilmesi gerektiğini ifade eder. Ona göre dinsel düşünce toplumsal ilerlemenin önünde bir ayak bağıdır ve bu ayak bağından kurtulmak gerekir (Iş̧ı 1985, 369).

II. Meşrutiyet döneminin en önemli düşünürlerinden bir olan Abdullah Cevdet ise, Ekrem Işın'ın sözleriyle "Osmanlı materyalizmine modern bir uygarlık anlayışı" kazandırmıştır. "Abdullah Cevdet'e kadar Osmanlı materyalizmi insan varliğının maddi temelleri üzerine soyut bir tartışma iken, onunla beraber modern uygarlığa ulaşmada izlenmesi gereken kapsamlı bir program niteliğini alır" (Işın 1985, 367). İçtihad adıyla çıkardığı dergide yılmaz ve radikal bir biçimde Batı uygarlığının savunuculuğunu yapmıştır. Ona göre tek bir uygarlık vardır, o da Avrupa uygarlığıdır (Hanioğlu 1981). Abdullah Cevdet'e göre modern uygarlığın temeli din ve geleneğin dışında laik bir kültür üzerine kurulmuştur. Kültürel yapının insan üzerindeki etkisine dikkat çeken Abdullah Cevdet Osmanlı toplumunun egemen kültürel yapısını çözümleyerek işe başlar. Bu konuda özellikle Gustav Le Bon'un Kitle Psikolojisi adlı eserinden hareket etmiştir (Ülken 1998, 250). Ona göre Osmanlı toplumunda din ve gelenek insanı 'tevekkül içinde' dondurmuştur. Biyolojik materyalizm izlendiğinde insanın gerçek doğasının bilinebileceğini, dolayısıyla gerçek özgürlüğün ve buna bağlı olarak gelişmenin sağlanabileceğini öne sürmektedir. Bu anlamda, Abdullah Cevdet'e göre, din yasaları uygarlık yolunda herhangi bir pozitif katkı sunmayacağı gibi, aksine bu yolda bir engel teşkil etmektedirler. Ziya Gökalp'le yakın bir ilişki içinde olan Abdullah Cevdet, hiç kuşkusuz, Cumhuriyet öncesi sekülarist düşünürlerin önde gelenidir. Söz konusu dönemde hiç kimse sekülarist vurgular bakımından Abdullah Cevdet'ten ileri gidememiştir.

Osmanlı materyalizminden söz ederken adı anılması gereken birçok başka düşünür vardır, fakat bunların hepsinden söz etmemiz gereksizdir. Ancak hemen bir saptama yapmamız gerekirse, materyalizme vurgu yapanlar Batıcılıkta dar anlamda pozitivistlerden çok öteye gitmişlerdir. Her şeyden önce materyalistler, yukarıda birkaç örnekte değindiğimiz gibi, bütünüyle dindışı bir perspektiften bakmaya çalışarak toplumda köklü bir seküler zihniyet yaratmak istemişlerdir. $\mathrm{Bu}$ çabaların esas olarak Cumhuriyet döneminde yankı bulduğunu söyleyebiliriz. Materyalist akımın yaptığı diğer bir etki ise bilimi 'kutsal' bir pozisyona getirmek olmuştur. Materyalist-pozitivist çizgide, hayatın maddi unsurlarına yapılan vurgu, neredeyse bütün tinsel hayatın maddi süreçlerle açıklanmaya ve böylece toplumun anlam dünyasını oluşturan dinsel geleneklerin zayıflatılmaya çalışılması kuşkusuz bir tepkiyle de karşılaşmıştır. Nitekim materyalist akım güçlenirken karşısında spritüalist bir gelenek de oluşmuştur (Toku 1996; Bolay, 2008). Genel olarak Batıcı akımlara karşı İslâmcı ya da Türk-İslâmcı çizgide gelişen spiritüalist felsefe, 
materyalizme ve pozitivizme karşı olarak insandaki tinselliğe ve toplumun dinsel ve geleneksel normlarına vurgu yapmaya çalışmıştır. Ancak tarihsel olarak bilmekteyiz ki, modernleşme sürecinde egemen olan düşünce çizgisi materyalist-pozitivist düşünce çizgisi olmuştur.

II. Meşrutiyet dönemi, aynı zamanda Türkiye'de sosyolojinin akademik olarak kurulduğu dönem olmak bakımından da bir düşünsel hareketliliğe tanıklık etmektedir. Yukarda bir vesileyle ifade ettiğimiz gibi, Batıyla ilişkilerin sonucunda Osmanlı aydınları arasında etkili olan Batılı felsefi ve sosyolojik akımlar hiçbir zaman 'hasbi' ve saf akademik bir ilgi konusu olmamıştır. En soyut gibi duran teorik, felsefi ve sosyolojik meseleler bile, her zaman, İmparatorluğun pratik sosyal-siyasal sorunlarını çözme kaygısı göz önünde tutularak ele alınmıştır. Sosyolojinin üniversitede akademik bir disiplin olarak eğitim müfredatına girdiği bu dönemde bile bu sözünü ettiğimiz durum hep devam etmiştir. Örneğin, aşağıda kendisine geniş bir yer vermeye çalışacağımız ve Türkiye'de sosyolojinin kurucusu olarak kabul edilen Ziya Gökalp'ın bütün sosyolojik ilgisi İmparatorluğun içine bulunduğu durumun 'bilimsel' olarak tespit edilmesi ve güçlü bir toplumun hangi öğeler üzerinde yükseltilebileceği meselesi etrafında yoğunlaşmıştır. $\mathrm{Bu}$ açıdan, baştan itibaren Türk sosyolojisinin her zaman, siyasal bir içerik taşıdığ ve siyasal bir işlev üstlenmiş olduğu, sosyolojinin siyasal ilgisinin mevcut devletin ihtiyaçları çerçevesinde biçimlendiği ve sosyolojinin de çoğu zaman resmî ideolojinin üretilmesinin araçlarından biri olarak görüldüğü öne sürülmektedir (Aktay 2002, 62-76; Çelebi 2001, 8-9, 20).

Osmanlı'da sosyoloji Hikmet-i Íctimaiyye, Ilm-i İctimai, İctimaiyyat gibi terimlerle karşılanır. Bu terimler sosyolojinin yerine kullanılır, ancak Zafer Toprak'ın ifade ettiği gibi "II. Meşrutiyetin gündeme getirdiği içtimaiyatın boyutları bu günkü toplumbilimden çok daha geniştir. Eli kalem tutan herkes içtimaiyattan söz eder. İçtimaiyatın çözüm getirmediği sorun hemen hemen yok gibidir" (Toprak 2002, 310). Öyle anlaş1lmaktadır ki, sosyoloji, dönemin düşünürlerince dar anlamda sosyoloji olarak değil daha çok bir sosyal-siyasal teori, hatta bazılarında bir ideoloji olarak tasavvur edilmektedir. Osmanlıda sosyoloji tasavvurunu biçimlendiren sosyoloji, kuşkusuz Batı sosyolojisidir. Her ne kadar İbni Haldun çok önceden bilinmekteyse de Osmanlı düşünürlerince o, sosyolog olmaktan çok bir tarihçi olarak görülmüştür (Şener 1998, 44). İbni Haldun sosyolojisinin içerdiği döngüsellik, yani her devletin doğal bir ömrü olduğu ve bu doğal ömrünü dolduran bir devletin kaçınılmaz olarak tarih sahnesinden silineceği görüşü, amacı İmparatorluğu korumak ve istikrara kavuşturmak olan Tanzimat sonrası dönemin Osmanlı aydınlarınca zaten kabul göremezdi. İbni Haldun'un II. Meşrutiyet döneminde ve sonrasında da bir etkisi olduğu söylenemez.

Ahmet Şuayb, Mehmet Cavit ve Rıza Tevfik'in çıkardığı Ulum-ı Íktisadiye ve Iç̧timaiye adlı dergide (ki bu dergi ilk sosyoloji dergisi olarak kabul edilir) Spencer'ın, Comte'un, Durkheim'ın görüşlerinin tanınması konusunda epeyce bir yazının yayımlandığı bilinmektedir. M. Zekeriya Sertel'in yazılarının yayımlandığı Bilgi Mecmuası adlı dergide ise Montesquieu'nün, Spencer'ın, Darwin'in, Durkheim'ın, Levy Bruhl'ün, Tarde'ın görüşlerine yer verilmiştir. Genç Kalemler çevresinde ise, özellikle Mustafa Suphi'nin yazılarında Durkheim tanıtılmıştır (Toprak 2002, 310-311). Bu dergilerde yayınlanan yazılar sosyolojinin Türkiye'deki serüvenini kuşkusuz bir ölçüde etkilemiştir. Ancak Türkiye'de sosyolojinin gelişim çizgisini oluşturan, onu aynı zamanda akademik bir disiplin olarak da Türkiye'de kuran, yukarıda da Ziya Gökalp olmuştur. Dönemin üniversitesi olan Darülfünun'da Gökalp'in İlm- $\iota$ İçtima adıyla okuttuğu ders tamı tamına sosyolojidir ve bu derslerde o ağırlıklı olarak Durkheim'a yer vermektedir. Gökalp'in Durkheim'a ilgisi sadece akademik bir ilgi değildir; o Durkheim sosyolojisinde, yaşadığı toplumun sorunlarını kavramanın ve toplumun ihtiyaç duyduğu istikrarı oluşturmanın kavramsal araçlarını bulduğunu düşünmektedir. Hemen belirtelim ki, II. Meşrutiyet döneminde sadece Ziya Gökalp ve Durkheimcı sosyoloji geleneği yoktur; Prens Sabahattin'in temsilcisi olduğu Le Play geleneği de bilinmektedir. Ancak II. 
Meşrutiyet döneminde etkili olan ve Cumhuriyetin kurucu ideolojisini de büyük ölçüde belirlemiş olan Ziya Gökalp ve onun izlediği sosyoloji geleneği olmuştur. Bu nedenle burada, Ziya Gökalp'in görüşlerine biraz daha geniş yer vermemiz gerekmektedir.

Ziya Gökalp Türk düşünce tarihinde yeri en çok tartış1lan düşünürlerin başında gelmektedir. Tartışma Gökalp'in bir sosyolog mu, yoksa bir ideolog mu sorusu etrafında yürütülmektedir. $\mathrm{Bu}$ konuda, Peyami Safa'nın Gökalp hakkında yazdığı bir makalede öne sürdüğü "Gökalp ilmin istediği objektif görüşe sahip bir sosyolog değildi, sosyolojide kendine has hiçbir çalışmast ve buluşu yoktur. Gökalp bir ideologdur. Gökalp’i bir sosyoloji âlimi olarak anlamaya kalktığımız anda önümüze çıkan adam Durkheim' 'n alelade bir müterciminden başka bir şey olamaz. Fakat Gökalp’i bir cihan telakkisinin kâş̧ifi gibi anladığımız anda karşılaştığımız adam, görüşünün ufuklar ilmin çevresini kat kat aşan ve hocası Durkheim'ı fersah fersah geride birakan büyük bir mürşit ve müjdecidir" görüşünü eleştiren Niyazi Berkes şöyle demektedir: "Bu sözler Gökalp’i haddinden fazla küçülten ve haddinden fazla büyüten sözlerdir. Gerçekte ne Gökalp’i ne Durkheim'ı ne de toplumbilimini anlamış olan bir anlayışın ifadesidir. Gökalp Durkheim 'in siradan bir çevirmeni değildir; sosyolojide kendine özgü (yani Durkheim'dan ayrı) düşünceleri vardır. Peyami Safa'nın anladı̆̆ d dünya görüsünün ne ilk ne de tek müjdecisi değildir. Ĕ̆ger Gökalp (şimdiki sosyologlarımızın yaptığı gibi) sosyolojiyi bilimsel bir sosyoloji dedikodusu şeklinde anlamamışsa ve içinde bulunduğu toplumun sorunlarından hareket ederek bu sorunları çözmeye çalışmışsa ve eğer bu mutlaka ideoloji demekse, Peyami Safa' ya haber verelim ki böyle olmayan bir sosyolog bulamayacaktır. Durkheim da öyledir, fakat Gökalp'ten farklı olarak" (Berkes 1985, 200-201). Gökalp'e ilişkin tartışma, kuşkusuz, burada andığımız bu görüşlerle sınırlı değildir, ama tartışma ekseni budur. Öyle anlaşılmaktadır ki Gökalp kendine özgü sorunları olan bir toplumda Durkheim'1 izlerken, onu söz konusu toplumun siyasal meseleleri açısından yorumlamıştır ve bu bakımdan aynı zamanda kendine özgü görüşler de ortaya koymuştur. Bu yüzdendir ki, Gökalp aynı zamanda bir sosyolog ve bir ideologdur.

Gökalp içinde bulunduğu toplumun sorunlarını nasıl formüle etmekteydi ve bu sorunlara nasıl bir sosyolojik çözüm önermekteydi? Batı'nın gerisinde kalan Osmanlı toplumunun ciddi bir değişim süreci geçirdiği muhakkaktı. Ancak muhakkak olan bir başka şey de bu değişim süreci içinde toplumun bütünlüğünün de tehlikede olduğuydu. Batı toplumlarının modernleşme sürecinin taşıyıcı öznesi ulustu. Dolayısıyla Batıda modernleşme ve modern ulus-devletin inşası eşzamanlıdır. Osmanlının modernleşme sürecinin taşıyıcısı olabilecek homojen bir öznesi yoktu. Daha doğrusu, yukarıda da ifade ettiğimiz gibi, modernleşme süreci aynı zamanda böyle bir öznenin yaratılması süreci olarak da okunabilir. Gökalp'e göre bu değişim sürecinde Batının kurum ve değerlerini bütünüyle ithâl etmek ve bu süreçte toplumun organik dokusunu oluşturan değerlerden vazgeçmek toplumun bütünlüğünü zedelemek olacaktır. Nihaî sonucu bakımından düşünülürse bu, toplumun yok olma tehlikesi ile karşı karşıya olduğu anlamına gelmektedir. Gökalp'e göre ne Batıcılar ne de İslâmcılar, kendi dar perspektiflerinde kaldıkları sürece, bütünlüğü ve ilerlemeyi ya da daha yerinde bir ifadeyle birlik içinde ilerlemeyi sağlayamaz ve söz konusu tehlikeyi aşamazlar. Gökalp kendi çözüm formülünü, yazdığı bir yazıya verdiği başlıkta ifade eder: Türkleşmek, İslâmlaşmak, Muasırlaşmak. Öyle anlaşılmaktadır ki, Gökalp'in çabası bazılarının uzlaşmaz saydığı, bazılarınınsa ancak çelişkilerle birlikte bir arada varolacağını düşündüğü "ulusal, dinsel ve Batılı düşünsel gelenekleri tek bir kuramda toplamaya yönelikti” (Parla 1989, 35).

Bunu yaparken Gökalp ulus, din, ümmet, kültür, uygarlık gibi kavramları analiz eder ve onları tanımlamaya girişir. Gökalp'e göre çağımız artık kavim ve ümmet döneminin geride bırakıldığı, ulusun esas alınarak toplumun inşa edildiği bir çağdır; Türk toplumu da kavim ve ümmet dönemini geride bırakmıştır. Bu yüzden o öncelikle, 'ulus nedir?' sorusundan başlar. Ona göre ulus ne ırka ne kavme dayanan bir şeydir. Ne Osmanlıcıların sandığı gibi bir ülkede 
oturan insanların toplamına işaret etmektedir, ne de İslâmcıların sandığı gibi sadece bir dine mensup olmak demektir. Berkes, Gökalp'in ulus tanımını şu beş noktada toparlamaktadır: 1) Ulus kendine ait bir dini olan, müşterek duyguları ifade eden kültür ile birleşen bir zümredir. 2) Ulus, ırk ve kavmiyet yönünden türdeş olmayan bir zümredir. 3) Ulus modern lâik uygarlığa katılmakla milletlerarası bir uygarlığa dâhildir. 4) Ulus demokratik, yani ulusun egemenliğine dayanan bir devlet zümresidir. 5) Ulus ümmet hayatından çıkmış; dini ulusal dile geçirilmiş ve ulusal hayat şeklinde yaşanan kurum haline gelmiş bir zümredir (Berkes 1985, 204). Bu belirlemeler 1şı̆̆ında diyebiliriz ki, Gökalp için ulus hem özgül olanı hem evrensel olanı; bir başka ifadeyle hem kültür kavramını hem uygarlık kavramını, Gökalp'in sözleriyle ifade edersek, hem harsı hem medeniyeti içermektedir. Kültür (hars) ve uygarlık (medeniyet) arasında yaptığı ayrım bir yandan yerel olanı korumayı öte yandan da Batıya entegre olmayı da mümkün kılmaktaydı. Gökalp'e göre kültür (hars) bir toplumun öznel ahlâkî normlarını, toplumsal vicdanını, estetik değerlerini ve genel ülkülerini ifade eder ve bu bakımdan sadece bir ulusa özgüdür. Uygarlık ise farklı uluslarca paylaşılan bir şeydir. Yine Berkes'e dayanarak ifade edersek, Gökalp için "uygarlık ulusal ve bireysel iradelerle meydana gelir, taklit yoluyla bir ulustan başka bir ulusa geçer. Kültüre dâhil olan şeylerse, doğal ve kendiliğinden meydana gelir; taklitle bir ulustan diğerine geçmez. Kültür özellikle duygulardan, uygarlık özellikle fikirlerden oluşur. Bir uygarlı̆̆ın bilimsel kavramları, teknik araçları, ekonomik ürünleri taklit ve değişim yoluyla bir halktan diğer halka geçer... Kültür bize amaçlarl, uygarlık araçları verir" (Berkes 1985, 206-207). Bu kavram çözümlemesinin amacı bellidir: Batının norm ve değer dünyasından etkilenmeksizin, ulus kavramı temelinde, Batının bilimsel birikiminden, teknolojik ve ekonomik ürünlerinden yararlanarak modernleşmek.

Modernleşmek ya da çağdaşlaşmak, Gökalp'e göre, Batının ahlaki değerlerine uymaksızın veya genel olarak Batılı hayat tarzına girmeksizin de mümkündü, ancak çağdaşlaşmak basit olarak Batının teknik ve ekonomik ürünlerine tâbi olarak da gerçekleştirilemezdi. Çağdaşlaşmak kuşkusuz bir yanıyla çağdaş uygarlığa ya da Batı uygarlığına katılmakla mümkündü; ancak yine hiç kuşkusuz bu, güçlü bir kültürel veya ulusal dayanışma ekseninde olursa ancak gerçek anlamda bir çağdaşlaşma olabilirdi. Gökalp'in içtimai mefkûrecilik dediği şey bu sentezin ifadesidir. Gökalp'in içtimai mefkûreciliğini tanımlamak için ifade ettiği Türk milletindenim, Íslam ümmetindenim ve Garp medeniyetindenim sözüne dikkat çeken Parla şu saptamayı yapmaktadır: "Gökalp'e göre Türk milliyetçiliği, kültürel bir ideal ve toplumsal dayanışma ve birliğin temelini oluşturacak bir yaşam felsefesini temsil ediyordu... Onun milliyetçiliği ırkçı veya yayılmacı olmayan eşitlikçi bir milliyetçilikti. Aynı şekilde İslamiyet'ten aldıkları da ortodoks ögretiler değil, tasavvuftan kaynaklanan, siyasal değil ahlâksal yönelimli ve yine toplumsal dayanışmayı güçlendirici öğelerdi. Gökalp’in toplum modelinde Türkçülük kültürel normu, İslâm da ahlâksal normu oluşturmaktaydı... Gökalp Türk kültürü ve İslâm tasavvufunun belli bir yanı, komünalizm ile Avrupa'nın solidarist korporatizminin bunlara karşıllk düşen öğeleri arasında olası bir uyumluluk bulmaya çalışmıştır" (Parla 1989, 35-36).

Gökalp'e göre toplumsal gruplar arasında, bu gruplar ister kültür ister uygarlık grupları olsun, aynı şekilde her bir kültürel grubun kendi iç zümreleri arasında çatışma ve gerilimler olabilir. Toplumda kademeleşmeler vardır ve kademeleşmeler muhtemel bir toplumsal çatışmanın kaynağıdırlar. İşte sosyoloji bir bilim olarak tam da bu noktada devreye girmektedir. Sosyolojinin amacı toplumdaki hiyerarşinin yaratabileceği çatışmaların nedenini keşfedip toplumda uyum ve birliği sağlamaktır. Gökalp'e göre toplumda aile, meslek ve siyasal olmak üzere üç grup vardır. İdeal bir toplum düzeni söz konusu bu gruplar arasında uyumu ve dayanışmayı sağlayarak gerçekleştirilebilir. Toplumsal işbölümü ideal bir toplum düzeninin temelidir. Gökalp'in Durkheimcılı̆̆ konusunda Marx'ın sınıf çatışması kuramının farkındadır, ancak o, "Durkheim'ın Socialisme kitabına dayanarak, grup, zümre ya da sınıf çatışmalarını meslek örgütleri dayanışmasıyla, yani 
korporatizmle çözmeye çalışır" (Hilav 1995, 368). Hatta o, korporatizmin, toplumların evriminde sınıflı toplumlardan sonra gelecek bir aşama olduğunu düşünmektedir. Korporatizm özel mülkiyeti ve özel girişimi esas alan bir görüştür. Bu bakımdan o sosyalizme karşıttır. Ancak aynı zamanda liberalizme de karşıttır. Birinci Dünya Savaşı'ndan sonra ortaya çıkan, antiliberal olan ancak anti-kapitalist olmayan korporatizmin iki alt türü vardır: Solidarist ya da dayanışmacı korporatizm ve faşist korporatizm. Taha Parla'nın Gökalp üzerine ayrıntılı incelemesinde ortaya koyduğu gibi, Gökalp'in korporatizmi solidarist korporatizmdir ve bunun kaynağı da açıkça Durkheim'dır (Parla 1989, 67-78).

II. Meşrutiyet döneminde 'tesanütçülük' kavramıyla karşılanan solidarizm genel olarak İttihatçı düşünürlerin gündeme getirdiği ve tek parti iktidarı boyunca etkili olan bir öğreti olmuştur. Ancak öyle anlaşılmaktadır ki bu öğretiyi Türk toplumunun özgül koşullarına göre formüle eden Gökalp'tir. Ancak bu konuda Gökalp yalnız değildir. Zafer Toprak bu konuda, "Solidarizm toplumbilimin Osmanlı için çizdiği yörüngedir... Ziya Gökalp, Tekin Alp, Necmettin Sadak, A. Mithat, Halim Sabit, Ahmet Emin, M. Zekeriya soldarizmle dirsek temasın hemen her yazılarında sürdürürler. Ancak solidarizmin Osmanlı’ya özgü kuramsal çerçevesi büyük ölçüde Gökalp ve Tekin Alp'in eseridir" tespitini yapmaktadır (Toprak 2002, 313). Gökalp solidarizmi 'içtimai halkçılık' olarak tanımlar ve bununla 'bireycilik'le 'toplumculuğu' uzlaştırmaya çalışır. Gökalp'e göre solidarizm zaten Türk hukukunun içerdiği bir şeydir ve o 'milli bir meslek', ulusal bir öğretidir (Toprak 2002, 314). Batının ilerlemesinin pozitif bilim zihniyetinin yanı sıra, bir bakıma bu bilim zihniyetinin sonucu olarak gelişen ekonomisine bağlı olduğunu düşünen Gökalp rekabetçi liberalizmin tabakalar arası çatışmalara yol açtığının farkındadır. Bu nedenle batının özel teşebbüsçü ve rekabetçi ekonomik düzenini, milliyetçilikten ve İslâm ahlakından türettiği dayanışma duygusuyla sentezlemeye çalışır. Gökalp uygarlığın bencil, yararcı ve çıkarcı yanlarına kültürün fedakâr, kamucu idealist yanıyla karşı durmaktadır. Parla'ya göre Durkheim, "bir yöntem ve epistemoloji olan pozitivizm ile idealist bir toplum felsefesinin sentezini yapmaya çalışıyor, böylece idealle gerçekliği 'bilimsel' yoldan birbirine bağlamayı umuyordu. Gökalp de bu iyimserliği paylaşmıştır. Pozitif bilimlerin, özellikle sosyolojinin ilerlemesi ve toplumsal sorunlara uygulanmasıyla imparatorlukların dağılacağına ve ulusların demokratikleşeceğine inanıyordu. Sosyoloji biliminin dayanışmacı bir niteliğe sahip olacă̆ını, toplumsal uyum ve ilişikleri incelerken kamuculuk (umumculuk) gibi normatif öncüllerden hareket edeceğini kabul etmişti” (Parla 1989, 41).

Ziya Gökalp sosyolojisinin, ayrıntılarında üzerinde durulabilecek başka birçok öğesi vardır, fakat amacımız Gökalp'in Türk modernleşmesi ve Türk sosyoloji tarihi açısından yerini saptamak olduğu için, burada ayrıntılara girmemiz gereksizdir. Ancak şunu saptamak gerekir ki, Gökalp'in görüşleri, Türk modernleşme tarihinin en önemli merhalesi olan Cumhuriyet'in kurucu ideolojisinin temel dayanaklarından biri olmuştur. Yeri geldiğinde tekrar değineceğiz, ama burada da belirtelim ki, Milliyetçilik, Lâiklik, Devletçilik, Halkçılık vb. ilkeler genel olarak II. Meşrutiyetin özel olarak Gökalp'in 'mefkûresi'nin Cumhuriyete devrettikleridir. Bunun gibi sosyoloji, kuruluş anından itibaren üniversitelerde esas olarak Gökalp'in belirlediği ComtecuDurkheimc1 pozitivist çerçevede gelişmiştir.

II. Meşrutiyet döneminde, sosyoloji söz konusu olduğunda ön plânda olan Durkheimc1 Gökalp’tir, ancak bilmekteyiz ki bu dönemde başka bir sosyoloji ekolünden olan ve Le Play geleneğini izleyen Prens Sabahattin de vardır. Jön Türklerin önde gelenlerinden olan Prens Sabahattin, toplumun kurtarılmasına yönelik saptamaları ve önerdiği çözüm bakımından, Gökalp'in de içinde yer aldığı İttihat ve Terakki geleneğinden ayrılır. Prens Sabahattin'e göre toplumun yapısını değiştirmedikten sonra adına ister meşrutiyet ister cumhuriyet, ne dersek diyelim sonuç her halükârda siyasal baskıcılığa dönüşecektir. Devletin merkezî gücünün azaltılması ve yönetimde özerklik anlamında kullandığı adem-i merkeziyet Prens Sabahattin'in 
önerdiği siyasal modeldir. Görüşlerini, yazdığı Türkiye Nasıl Kurtulur? adlı eserde dile getiren Sabahattin'e göre imparatorluğun kurtuluşunu mümkün kılacak şey kamисu yapıdan bireyci yapıya geçmektir (Durukan 2002, 140). Osmanlı'nın gerileyişinin en önemli nedeni kamucu mülkiyet yapısıdır. Bu açıdan Prens Sabahattin ekonomide teşebbüsü şahsi, yani özel girişimci modelinin uygulanması gerektiğini düşünür. Adem-i merkeziyet ve teşebbüsü şahsi ile devletin bürokratik yapısının zayıflayacağını düşünen Prens Sabahattin bunun için bir burjuva sınıfı yaratmak gerektiğini düşünür. Avrupa'ya ilişkin gözlemi ona, özel mülkiyetin ve özel girişimin söz konusu uygarlığın ilerlemesindeki en önemli faktör olduğunu düşündürtmüştür. Bu açıdan Prens Sabahattin Osmanlı'nın ilk liberali olarak kabul edilir. Gerçekten de o dönemin hemen hemen tüm aydınlarından farklı olarak Fransa yerine liberalizmin ve bireyciliğin merkezi İngiltere’ye ilgi duymaktadır (Berkes 1985, 139).

Osmanlı toplumunun yapısına ilişkin geliştirdiği bu görüşlerden ötürü Prens Sabahattin, Gökalp'in de etkin üyelerinden olduğu İttihat ve Terakki'yle anlaşmazlığa düşer. Baykan Sezer'e göre Prens Sabahattin bu anlaşmazlığını aynı zamanda sosyoloji anlayışlarındaki farklılıklara başvurarak da gerekçelendirmeye çalışmıştır (Sezer 1989, 73). Bilindiği gibi İttihat ve Terakki'de egemen olan sosyoloji anlayışı Comtecu-Durkheimcı sosyolojidir. Prens Sabahattin ise, Le Play ekolündendir. Bir Fransız sosyologu olan Le Play'ın görüşleri daha sonra Demolins, De Tourville, ve Descamps tarafından geliştirilmiştir. Prens Sabahattin söz konusu ekolden, daha çok kişisel ilişki içinde olduğu Demolins dolayısıyla etkilenmiştir. Demolins'in $A$ qui tient la supériorité des Anglo-Sakson? (Anglo-Saksonların Üstünlüğü Neye Bağlıdır?) adlı eseri bu etkide en başta gelmektedir. Demolins toplumları iki kavramdan hareketle analiz eder ya da toplumları iki yapıya indirger: Kamucu yapılar ve bireyci yapılar. Le Play ekolü sosyoloji yerine science social kavramını kullanır ve Prens Sabahattin'e göre gerçek bilim science socialdir, oysa sosyoloji daha çok bir toplum felsefesidir. Baykan Sezer'in ifadesiyle "Sabahattin Bey, Itttihat ve Terakki önünde kendisini hakl saymaktadır. Çünkü science sociale gerçek olumlu bir bilimken, sosyoloji bir toplum felsefesi olmaktan öteye gidememektedir... İttihat ve Terakki yanlış ve yetersiz bir toplum anlayışı nedeniyle sorunlarımızı yüzeysel bir biçimde kavramakta, sonucunda da önerdiği çözümler Türkiye koşulları önünde etkisiz kalmaktadır" (Sezer 1989, 73-74). Prens Sabahattin'in Türkiye'ye yönelik görüşleri ne II. Meşrutiyet döneminde ne de bütün tek parti iktidarı boyunca her hangi ciddi bir etki yaratmamıştır. "Bireyin toplumsal önemini vurgulayan Le Play ekolünün etkisi Türkiye'de oldukça klsitlı kalırken Durkheim düşüncesi sosyoloji alanını hemen hemen etkisi alanına almıştır" (Mert 1993, 17). Çok partili dönemle birlikte liberalizm Türkiye'de, etkili olmasa bile sözü edilir bir öğreti olmaya başlamıştır.

\section{Cumhuriyet Dönemi: Kurucu İdeoloji Olarak Kemalizm ve Pozitivizm}

Cumhuriyet dönemi Türk modernleşmesinin, deyim yerindeyse dönüm noktasını oluşturmaktadır. Modernleşme eğer Batılılaşma/Batılılaştırılma olarak tanımlanırsa, bu dönem 'bütün' olarak Batılılaşma sürecinin başlangıcını temsil eder; geçmișin, eski toplumsal düzenin geleneksel kurumları ve değerleri kesin bir kararlılıkla Batılı kurumlar ve değerlerle değiştirilir. $\mathrm{Bu}$ anlamda, modernleşme çabasının Cumhuriyet dönemiyle birlikte doğru bir sürece girdiği ya da esas anlamını Cumhuriyet döneminde bulduğu ifade edilir. Tanzimat'tan bu yana yapılanları eksik ya da yetersiz olarak değerlendiren, Mustafa Kemal'in gerçekleştirdiği değişimleri Türk Aydınlanması olarak adlandıran Bedia Akarsu bunu şöyle ifade etmektedir: "Gerçi Tanzimat'la birlikte Aydınlanma felsefesinin ilkeleri kimi düşünürlerce ele alınmış, birtakım reformlara girişilmişse de, asıl kaynaklara inilemediği için başarıya da ulaşamamıştır. Kültürüne yönelmeden, o kültürü̈n ve uygarliğın kaynaklarına inmeden, bilimsel düşünüşe ve lâik düzene geçmeden Batının yalnızca tekniğini almaya kalkması, o tekniği yaratan temellere inmeyişi Tanzimat dönemini yalnızca 'Batı taklitçisi' olarak bırakmıştır. Ancak Atatürk'le birlikte 
teokratik düzen kökünden yıkllp ulus egemenliğine dayalı devlet düzeni kurulmuş ve Cumhuriyetin ilânından bir yıl gibi kısa bir süre sonra halifelik de kaldırılarak lâik düzene geçilmişstir. Böylece Batı Avrupa'da birkaç yüzyıl önce başlayan uyanış ve Aydınlanma çağları, çok geç de olsa bizde de başlamış oldu. Atatürk dönemi bir Türk Aydınlanma dönemidir" (Akarsu 1997, 88). Osmanlı'nın siyasal düzeninin dar anlamda bir teokrasi olup olmadığı bir tartışma konusu oluştursa da, burada bu tartışmayı sergilememiz gereksizdir. Ancak şurası açıktır ki, din Osmanlı siyasal düzeninde önemli bir yere sahipti ve yukarıda aktardığımız pasajda dikkat çekilen husus, Cumhuriyetin ulusal egemenlik kavramı temeline dayalı lâik bir düzen inşâ ettiğidir. Bunlar modernleşmeyi tanımlayan iki temel ilke veya modernleşmenin olmazsa olmaz iki koşulunu oluşturur: Ulus egemenliği veya ulus-devlet örgütlenmesi, siyasal alanın ve giderek bütün olarak toplumun din-dışılaştırılması ya da sekülerizasyon. Gerçekten de bunlar ne Tanzimat döneminin ne de Meşrutiyet döneminin modernleşme programlarında olmayan şeylerdi. Çünkü yukarıda yeri geldiğinde birkaç kez ifade ettiğimiz gibi, Cumhuriyete kadarki modernleşme sürecinde genel olarak İmparatorluğun siyasal örgütlenmesinde ciddi bir değişiklik yapma öngörülmemekteydi. Aynı şekilde toplumun bütünüyle din-dışı değerlerle tasarlanması da açık bir biçimde söz konusu edilmemişti. Daha önce de ifade ettiğimiz gibi, radikal lâik devlet programını açıkça dillendiren sadece Abdullah Cevdet olmuştu, ancak onun bu görüşü Z. Gökalp de dâhil dönemin siyasi aktörleri üzerinde pek de bir etki yaratmamıştı.

Bilindiği gibi Osmanlı İmparatorluğu, millet sistemine göre örgütlenmişti. Burada millet, kuşkusuz modern anlamda millet değildir; o daha çok dinsel bir topluluğu tarif etmektedir ve bu bakımdan Osmanlı toplum yapısının çok milletli olduğu söylenebilir. Bu durum siyasal erkin kaynağı konusunda bir sorun doğurmamaktaydı, çünkü erkin meşruiyeti millet değil, hanedanlıktı. Ancak Cumhuriyet egemenliğin kaynağını millet olarak tanımlamaktadır ve milletten kast edilen şey, Ziya Gökalp'in belirlemiş olduğu şekliyle, aralarında dil, kültür, 'mefkûre' ortaklığ olan topluluktur. Hemen vurgulamalıyız ki, bu tanımda 'din birliği’ şartı yoktur. Dolayısıyla eğer egemenliğin kaynağı millet ise ve millet de dine dayanmıyorsa siyasal erkin kaynağının tanımlanmasında da dinin bir rolü olmayacaktır; daha doğrusu rolü olmamalıdır. Cumhuriyetin kurucu iradesinin tanımladığı şekliyle yeni devlet örgütlenmesinde egemenliğin kaynağı, dindış1 verilerden hareketle tanımlanmış olan Türk milletidir. Modern Türkiye'nin kurucu ideolojisi esas olarak bu iki ilke üzerine dayanmaktadır. Diğer ilkeler bir bakıma bu iki ilkenin türevleri gibidir ve söz konusu ilkeleri güçlendirmeye, pekiştirmeye yöneliktirler. Şimdi modern Türkiye Cumhuriyetinin kurucu ideolojisini ele almaya ve bu ilkelerin oluşturulmasında pozitivizmin nasıl bir etkiye sahip olduğuna bakmaya çalışalım.

Bilindiği gibi Modern Türkiye'nin kurucu ideolojisi Atatürkçülük veya Kemalizm olarak tanımlanmaktadır. Şerif Mardin'in tanımıyla “Atatürkçülük, Cumhuriyet Türkiye'sinde; Osmanlı Imparatorluğu'ndan kalma bazı temel yapısal unsurları değiştirip onların yerine dünya uygarlığına gidişte ilk adım sayılan Batı uygarlığından esinlenmiş bir topluluk kurmak amacına yönelen bir görüştür" (Mardin 1991, 156). Atatürk'ün amac1, sık sık dile getirdiği gibi, muasır medeniyet seviyesine ulaşmış bir toplum kurmaktır ve muasır medeniyet Atatürk için kuşkusuz Batı medeniyetidir. Atatürkçülük veya daha yaygın olarak kullanıldığ 1 şekliyle Kemalizm dar anlamda bir öğreti olmaktan çok bir ilkeler bütünüdür. Atatürk'ün kurucusu olduğu Cumhuriyet Halk Fırkası'nın 10 Mayıs 1931 tarihindeki büyük kongresinde kabul edilen bu ilkeler Cumhuriyetçilik, Milliyetçilik, Halkçılık, Devletçilik, Laiklik ve İnklapçılıktır. Bu ilkelerin modern Türkiye'nin kuruluşunda nasıl bir işleve sahip olduğunu ve bu ilkelerin belirlenmesinde pozitivizmin ne tür bir etki yarattığını biraz daha açmamız gerektiği açıktır. Ancak önce şunu vurgulamalıyız ki, bu ilkelerin hayata geçirilişi bir dizi yukarıdan devrimle olmuştur ve bu zaman zaman, çok güçlü olmasa da, bir direnişle karşılaşmıştır. Özellikle toplumun geleneksel, dinsel anlam dünyasını oluşturan semboller ve değerlerle ilgili zorlamaya dayanan değişimler, etkileri bu gün halen devam etmekte olan toplumsal gerilimlere yol açmıştır. Bugün çoğulcu demokrasi kavramı temelinde Türkiye'de yürütülmekte olan tartışmaların olumlu ya da olumsuz 
referans kaynağı, söz konusu ilkelerin bizzat kendisi ve onların hayata geçiriliş biçimidir.

Kurtuluş mücadelesini başarıyla gerçekleştirdikten sonra Atatürk için temel amaç, yukarıda da ifade ettiğimiz gibi, toplumu çağdaş uygarlığın norm ve standartlarına yükseltmekti. Taner Timur'un ifade ettiği gibi 'medeniyet' kavramı Atatürk'ün bütün konuşmalarının leitmotifini teşkil eder (Timur 1983, 95). Çağdaş uygarlığı temsil eden Batı olduğuna göre, o halde Atatürk için hedef Batılı modele uygun bir toplum inşâ etmektir. Peki, Atatürk'ün perspektifinden Batı nedir veya Batıyı üstün kılan şeyler nelerdir? Bu sorunun yanıtını yine Timur'un ağzından vermeye çalışalım: "Atatürk'ün gördü̈̆̈̈ iki âlemi birbirinden ayıran şey, her şeyden önce fakirlik ve zenginlikti. Batı zengin, doğu ise fakirdi... Çağdaş medeniyete nasıl ulaşılacaktı? Bunun cevabı açıktır: iktisadi kalkınmayla" (Timur 1983, 95). Kuşkusuz Batıyı üstün kılan şeylerin başında, Batının ulaştığı refah düzeyi gelmektedir. Ancak Batı sadece yüksek refah düzeyi değildir; aynı zamanda, söz konusu refah düzeyinin de kendisi sayesinde gerçekleştiği bilimsel zihniyeti temsil etmektedir. O halde çağdaş uygarlığın iki temel belirleyeni ekonomik kalkınma ve bilimsel zihniyet veya bilimsel dünya görüşüdür. Buna dayanarak Türk toplumu açısından hedefin bilimin kılavuzluğunda yüksek refah düzeyini yakalamak olduğu söylenebilir. Bu durumda Kemalizm'in yukarıda andığımız ilkelerini bu çerçevede değerlendirmek gerekmektedir.

Kemalizm'in altı ilkesinin başında gelen Cumhuriyetçilik monarşik düzenin şahsi bağl1lık ilkesinin yerine yasaların üstünlügünü öngörmektedir. Cumhuriyetçilik ilkesinin peşinden gelen ve bir bakıma onun soyut çerçevesini dolduran ilke, Milliyetçilikte ifadesini bulur: Türkiye Cumhuriyetinde egemenliğin kaynağı kayıtsız şartsız, aralarında siyasi varlıkta birlik, dil birliği, 1rk ve menşe birliği, tarih birliği ve nihayet ahlâkî ideal birliği bulunan Türk milletidir. Dikkat çekmiş olmalıdır ki, millete ilişkin bu tanım büyük ölçüde Ziya Gökalp'in görüşleri çerçevesinde şekillendirilmiştir. Burada yeniden vurgulamamız gerekir ki bu tanımda 'din birliği' yoktur. 'Kurtuluş savaşı içinde dinsel özelliklerle tanımlanan millet kavramı 1930'larda oluşan Kemalist ideoloji içine, lâiklik ilkesinin bir sonucu olarak dinsel özelliklerinden arındırılmış bir biçimde girmiştir" (Köker 1990, 90). Atatürk'e göre Türkiye Cumhuriyeti'ni kuran Türkiye halkına Türk milleti denir ve Türk milleti, halk idaresi olan Cumhuriyetle idare olunur bir devlettir. Bu tanım devletle milleti özdeş saymaktadır. "Kemalist ideolojide devlet ile millet aynı şeydir Devlet ile millet özdeş varliklar olarak kabul edilmekte ve bu özdeşlik de aslında toplumdaki en üstün güç olarak egemenliğin millete ait olmaslyla açıklanmaktadır" (Köker 1990, 81). Bilindiği gibi 'ilerleme' fikri pozitivizmin temel kavramlarından biridir ve düzene bağlı olarak gerçekleşir. Cumhuriyetin kurucu iradesine göre ilerleme için gerekli olan düzen, daha önceki dönemlerde tanımlandığı şekliyle Osmanlı'yı oluşturan farklı etnik ve dinsel grupların 'birliği' (ittihat) ile değil homojen millet kavramı ile oluşturulabilir.

Kemalizm'in üçüncü ilkesi Türkiye Cumhuriyetini sınıfsız, imtiyazsız bir toplum olarak tanımlayan Halkçılık ilkesidir. Atatürk'e göre Türkiye'de Batıdaki gibi çıkarları birbirleriyle çatışan sınıflar yoktur; İzmir İktisat kongresinde yaptığı konuşmada kalkınmanın bütün sınıfların birlikte zenginleştiği ve toplumsal ahenk oluşturacak bir biçimde gerçekleşmesi gerektiğini belirtir. Halkçılık ilkesi sadece iktisadî bir ilke değildir; o bir boyutuyla da siyasî bir ilkedir. Çünkü bu ilke, aynı zamanda halkın siyasal hayata ve yönetime katılmasını öngörmektedir. Taner Timur'a göre: “halkçılık gerek sınıfsal anlamı gerekse siyasi yönüyle Atatürk'ü pozitivizme yaklaştırır. A. Comte'un 'toplumsal dokular' teorisi ve Durkheim'in organik ve mekanik işbölümü, kollektif bilinç fikri gibi, toplumu bir saatin çarklarl gibi ahenk içinde ele alan halkçıllk fikri de ancak pozitivist bir espiri içinde değerlendirilebilir".

Devletçilik ilkesi de bir anlamda ve esas olarak iktisadî bir ilkedir, bir anlamda da siyasî bir ilkedir. Buna göre Türkiye Cumhuriyetinin ekonomik olarak gelişebilmesi ve güçlü olabilmesi için özel şahısların el atamadıkları alanlarda devletin bizzat kendisi ekonomik kalkınmayı 
gerçekleştirmelidir. Devletçilik ulusal kalkınma fikrinin bir ifadesidir. Devletin iktisadî alanda aktif rol üstlenmesi, sadece ulusal kalkınmanın bir an önce gereçleştirilmesi ihtiyacından değildir. Hiç kuşkusuz bu kaygı önceliklidir, ancak bu ilke aynı zamanda iktisadî alanda hâkimiyet tesis ederek sınıfsız imtiyazsız bir toplum tasavvurunu da pekiştirmektedir. Devletçilik ilkesinin pozitivist siyasal anlayışıyla olan bağı da açıktır: Toplumun düzen içinde ilerleyebilmesi için güçlü, merkezî siyasal bir iktidar. Yukarıda da ifade ettiğimiz gibi esasen iktisadi bir ilke olan devletçilik, zamanla siyasi bir ağırlık kazanarak devleti toplumun merkezine koyan siyasi bir ilke olarak algılanmıştır.

Kemalizm'in diğer bir ilkesi olan İnkılâpçılık ise toplumun ilerlemesi için gerçekleştirilen değişimlerin ilerleme hedefine yönelik olarak sürekli kılınmasını ifade etmektedir ve aynı zamanda toplumsal değişimin şeklini tanımlamaktadır. Eric-Jan Zürcher'e göre "Mustafa Kemal ve taraftarlarının, bunu kullandıklarında kast ettiklerinin devrimden ziyade reformizm olduğuna şüphe yoktur... Kemalistler için (...) yukarıdan yönlendirilen bir dönüşüm idealdi ve bu konuda geç dönem Osmanl reformistleriyle hemfikirdiler" (Zürcher 2001, 51). Bunun 19. yüzy1l pozitivizminin toplumsal değişme anlayışının bir ifadesi olduğu açıktır. Daha önce de ifade ettiğimiz gibi, pozitivizm hiçbir şekilde devrimci dönüşümleri kabul etmemekte, hatta devrimci değişimlerin ilerleme önünde engel teşkil ettiğini öne sürmektedir.

Kemalizm'in Lâiklik ilkesi pozitivist siyaset teorisiyle belki de en sıkı ilişkisi olan ilkedir. Timur'un ifadesiyle “Kemalizm'i pozitivizm paraleline sokan diğer iki temel kavram ilim ve lâiklik kavramlarıdır" (Timur 1983, 95). Bilindiği gibi pozitivizm toplumu ve siyasal kurumları bütünüyle dindışı kategoriler olarak kabul etmektedir. Pozitivist toplum kuramında, özellikle Comtecu gelenekte dinin yerini bilimin alacağı öngörülmektedir. İslâm Osmanlı İmparatorluğu'nun hâkim ideolojisiydi. Ulema hem toplumun siyasal işleyiş mekanizmasında kısmen de olsa bir role sahipti, hem de genel olarak toplumun kanaat önderi konumundaydi. Dinin toplumun kültür ve geleneklerini, anlam dünyasının sembollerini büyük ölçüde belirlemiş olduğu da bir gerçektir. Bu bakımdan lâiklik ilkesi öncelikle siyasal bir ilke olarak anlam kazanmış, sonra da kültürel bir ilke olarak iş görmüştür. Yani o sadece devlet ve din işlerini ilkesel olarak birbirinden ayıran bir kavram değildir; o aynı zamanda genel olarak kültürün dindış1 içeriğe bürünmesine yol açmıştır.

Çok genel hatlarla ortaya koyduğumuz bu altı ilke 1922 ile 1937 arasında yukarıdan, devlet eliyle gerçekleştirilen bir dizi reformla hayata geçirilmiş̧ir: Sırasıyla saltanatın kaldırılması, Cumhuriyetin ilânı, tekke ve zaviyelerin kapatılması, uluslararası takvimin kabulü, medeni kanunun kabulü, anayasadan devletin dini 'din-i İslâm'dır' maddesinin kaldırılması, yeni Türk harflerinin kabulü... Bütün bunlar Türk toplumunun geleneksel kurum ve değerlerinin Batılı kurum ve değerlerle değiştirildiğinin örnekleridirler. Bu ilkelerin pozitivizmle ilişkisine çok kısa bir biçimde olsa da değindik. Ancak şunu vurgulamamız gerekmektedir ki, pozitivizm Kemalizm'in epistemolojisinin çok güçlü bir zeminini oluşturmaktadır ve bu bakımdan Atatürk'ün görüşlerinin oluşum sürecinde pozitivizmin etkisinin ne olduğuna biraz daha yakından bakmamiz gerekir (Arslan 1981, 45-85).

Daha önce de ifade ettiğimiz gibi, Atatürk amacının Türk toplumunu çağdaş medeniyet seviyesine yükseltmek olduğunu ifade eder ve ona göre çağdaş uygarlık nosyonunu Batı toplumu temsil etmektedir. Atatürk'e göre toplumlar çoktur ancak uygarlık tektir ve bir toplumun uygarlık sürecine katılması gerekir. Atatürk'e göre, Türk toplumunun, kendisini geri bırakan uygarlık çevresinden kopup Batı uygarlığı çevresine katılması gerekir. Açıkça ifade etmese de, Atatürk için kendisinden kurtulmak gereken değerler veya uygarlık çevresi, İslam'ın belirlediği uygarlık çevresidir (Arslan 1981, 64). Ona göre zaten, Batı medeniyetinin ilerlemesinin temelinde de Hıristiyanlığın hiçbir etkisi yoktur. Tam tersine batı medeniyeti dinsel- metafiziksel tasarımlardan kurtulduğu ve ilim ve feni esas aldığı içindir ki ilerlemiştir. 
"Pozitivist düşüncenin ana kaygllarından biri olan düşüncenin metafizik kayıtlardan ve metafizik problemlerden kurtarllarak pozitif bir biçime kavuşturulması kaygısının Atatürk'te de bulunduğunu söyleyebiliriz. Hatta Atatürk'te 'ünlü üç hal kanunu'nun kendisinin değilse bile ona benzer bir tarihsel evrim şemasının bulunduğunu söyleyebiliriz. Çünkü Atatürk'e göre de tarihte dinsel, metafizik düşünceden pozitif, akılcı düşünceye doğru bir evrim vardır. Ancak Atatürk, burada teolojik ve metafizik düşünce yerine daha ziyade 'Ortaçağ düşüncesi', 'hurafai zihniyet' gibi deyimler kullanır. Terakki fikri hem pozitivistlerde hem de Atatürk'te vardır" (Arslan 1981, 77). O halde şunu ifade edebiliriz ki, Atatürk'ün pozitivizmden aldığı en büyük etki bilimin üstünlüğü, bilimin tek ve evrensel doğruyu temsil ettiği görüşüdür. Atatürk'ün bilim vurgusu Avrupalı pozitivistlerden, özellikle de Comte'unkinden bir ölçüde ayrılmaktadır. Çünkü St. Simon, A. Comte bilimden söz ettiklerinde, bundan toplumun elit- bilim adamlarının yönetmesi gerektiği sonucunu da çıkartmaktaydılar. Oysa Atatürk için pozitif düşünce ve bilim hayranlığı, Türk insanın aydınlatılması, kendi hayatını kendi eline almasının sağlanması ve tüm yaşamının demokratikleştirilmesi anlamına gelir (Arslan 1981, 81). Kuşkusuz bu tespit bir ölçüde doğru olsa da, bilimin üstünlüğü kavramı Atatürk'te de tam da Comte'daki türden bir içeriğe sahip olmuştur. Nitekim modern Türkiye'nin kuruluşunun elit-aydının eliyle gerçekleştirildiği tarihsel bir olgudur.

Taner Timur Atatürk'ün pozitivizme yakınlığının konjonktürel olduğunu öne sürmektedir. Pozitivizmin Atatürk'ün gerçek devrimciliğine, tam bağımsızlıkçı duruşuna cevap vermediğini ifade eden Timur'a göre, "sınıf çelişkilerinin keskinleşmediği bir dönemde, Atatürk, orta sınıf radikalizminin bir temsilcisi olmuştur. Zamanın koşulları içinde egemen sınıflarla işbirliği yapmıştır. Fakat hiçbir zaman iktidarı egemen sinifların bir aracı haline getirmemiştir... Atatürk liderliğindeki siyasi iktidar yar-feodal düzeni saltanat-hilafet kurumları aracılı̆̆lyla savunan akımlara (Ikkinci grup Terakki Perver Fırka) pozitivizmle karşı çıkmıştır" (Timur 1997, 104-105). Atatürk'ün pozitivizm gibi muhafazakâr bir ideolojiye yakınlığının ilkesel mi yoksa konjonktürel mi olup olmadığı meselesini tartışmak kuşkusuz önemlidir. Ancak yine tarihsel bir olgudur ki, modern Türkiye Cumhuriyeti pozitivist epistemoloji ve siyaset öğretisi temelinde inşa edilmiştir; bu epistemoloji ve siyaset öğretisi Kemalizm'de vücut bulmuştur.

Atatürkçü modernleşme sürecini genel olarak bu çerçevede değerlendirirsek, bu projenin homojen ulus-devlet ve seküler bir toplum oluşturmayı hedeflediğini söyleyebiliriz. Bu bakımdan Erik-Jan Zürcher'in ifade ettiği gibi Milliyetçilik ve Laiklik Kemalist ideolojinin temel belirleyenleridir (Zürcher 2001, 44). Kemalizm bu temelde yeni bir 'kimlik' yaratmak istemektedir ve bu anlamda o 'inşa edici' bir zihniyet karakterine sahiptir. Yeni toplumun geleneği "geçmiş ile süreklilik oluşturan bir şekilde icat edilmemiş, aksine geçmiş ile bir kopuş, tarihsel bir kırılma oluşturmuştur... 'Modernleşme arzusu'nun dürtülerini dikkate alan ve modernleşmeyi bir erek olarak gören Cumhuriyet seçkinleri, modern ethosun henüz yerleşmediği bir dönemde modern kurumları birbiri ardına sıralamışlardır" (Kadıoğlu 1999, 20-33). Aç1ktır ki, bunun toplumsal gerilime yol açan sonuçları olmuştur ve kuşkusuz bu gerilimlerin başında da söz konusu iki ilkenin, yani Milliyetçilik ve Lâiklik ilkesinin kavranış ve uygulanış biçimlerinin yarattı̆g 1 gerilimler gelmektedir. Kemalizm'in modernleşme projesi ve özellikle Milliyetçilik ilkesi "Osmanlı kimliğini ortadan kaldırırken cemaatsel kimlikleri de çok daraltılmış olan özel alana hapsederek, bireysel olarak yaşanabilen folklorik özelliklere indirgedi" (Mahçupyan 1998, 62). Özellikle Lâiklik ilkesinin bütün hayatın ve kültürün dindış1 bir biçimde düzenlenmesi şeklini alması, başka bir ifadeyle Lâikliğin sekülarizm formuna büründürülmesi günümüzde de halen devam etmekte olan bir gerilimin kaynağını oluşturmaktadır (Mert 1994). Bilimin üstünlüğüne duyulan inançla "Lâiklik bilimsel sayılmış ve kamusal alanın dinden temizlenmesinin aracı olarak algilanmıştır" (Mahçupyan 2000, 211).

Pozitivizm Türkiye'de Batıda olduğundan farklı sonuçlar doğurmuştur. Bunun en önemli 
nedeni, Batıda pozitivizmin, çeşitli felsefî siyasi görüşlerin de mevcut olduğu bir atmosferde algılanmış ve bu bakımdan güçlü eleştirilere uğramış olmasıdır (Özlem 2002). Osmanlı'dan başlamak üzere genel olarak Türk modernleşme tarihinde ise pozitivizm, bir bakıma 'mutlak doğru'yu temsil eden bilimsel bir kuram, bir yandan bunun bir izdüşümü olarak da 'mutlak doğru' bilimsel bir siyasal ideoloji olarak algılanmıştır (Mahçupyan 1998, 60-61). Açıktır ki bu totaliter bir zihniyetin oluşmasına yol açmıştır. "Pozitivizm her iki tarafta da egemen görüş olmasına rağmen çok farklı toplumsal işlevler gördü. Batıda içsel bir dinamiğin sonucuydu ve toplumla devlet arasında temel bir ayrışmaya neden olmadiğ gibi, iki unsuru birleştiren bir özgüven de yarattı. Oysa Osmanlı'dan Türkiye'ye doğru yaşanan tarihsel süreçte pozitivizm dışsal bir model, bir norm olarak işlev gördü ve devletin toplumu baskı altına alarak biçimlendirmeye çalışmasının ardındaki meşruiyeti sağladı" (Mahçupyan 1998, 61).

\section{Türk Modernleşmesi, Pozitivizm ve Sosyoloji: Bir Değerlendirme}

Yukarıda genel hatlarla göstermeye çalıştığımız gibi pozitivizm, Türk modernleşme sürecinin başlangıcından itibaren etkili olmuş bir Batılı düşünce geleneğidir. Burada bir kez daha ifade etmemiz gerekmektedir ki, bu düşünce geleneği, en genel anlamda, modern doğa bilimleri kavramını model alarak bir toplumsal ve siyasal teori geliştirmek amacındandır. Hatta söz konusu amacı gerçekleştirdiği iddiasındadır. Kuşkusuz onun bu amacı ve iddiası Türk toplumundaki temsilcileri tarafından da paylaşılmaktadır. Nitekim Türk modernleşme sürecine kabaca bir göz atarak ortaya koymaya çalıştığımız gibi, pozitivizmin Türk toplumundaki temsilcilerine göre de tıpkı doğanın olduğu gibi toplumun da zorunlu yasaları vardır ve bu yasalar 'bilimsel' olarak bilinebilir. Nasıl ki doğanın zorunlu yasaları keşfedildiğinde doğa bir bakıma kontrol altına alınabiliyorsa, aynı şekilde toplumun yasaları bilindiğinde de toplum kontrol altına alınabilir ve düzenlenebilir. Aslında bu iddia ilk bakışta çok nötr ve 'bilimsel' bir iddia olarak görünmektedir. Ancak söz konusu iddia aynı zamanda ve doğal olarak toplum ve siyaset 'uzmanı' kavramını da içermektedir ki, buradan toplumun da, esas olarak, toplum ve siyaset 'uzmanlar'1 tarafindan yönetilmesi gerektiği sonucu çıkmaktadır. Bu açıdan pozitivist sosyolojinin, bir tür toplum mühendisliği için gerekli olan teorik, 'bilimsel' araçları sunduğunu ve bir tür toplum mühendisliğine hizmet ettiğini söyleyebiliriz. Buna dayanarak yine vurgulayabiliriz ki, bu 'bilimsel' bakış açısı çok hızlı bir biçimde 'bilimsel' bir siyasal ideolojiye dönüştürülebilir. Pozitivizmin Türk modernleşmesi sürecindeki serüveni tam da bu tespitimizi doğrular gibi görünmektedir. Özellikle, Türk modernleşmesinin dönüm noktası olan Cumhuriyetin kuruluşuna önderlik etmiş kadrolar bu 'bilimsel' bakış açısından 'bilimsel' ideolojiye geçişi çok hızlı bir biçimde gerçekleştirmişlerdir. "Cumhuriyetin önderleri, pozitivizm, toplum mühendisliğine kapı aralayan elverişli bir mantık sergilediği için onu klâsik geleneği reddetmenin biricik aracı olarak gördüler. Toplum pozitivizmin çizdiği doğru evrim şemasının dışındaydl, yanlış yaşıyordu ve değiştirilmeliydi" (Arslan 1992, XV).

Türk toplumunun 'doğru evrim şeması'na sokulması, onun seküler bir tarzda ve ulus-devlet temelinde yeniden inşâ edilmesi, başka bir deyişle modernleş(tiril)mesi demekti. Toplumun geleneksel yapısından bütünüyle farklı olan bir başka kalıba sokulması, açıktır ki geleneksel norm ve değerlerden hareketle gerçekleştirilemezdi. Modern toplumun seküler, modern dayanakları olmalıydı; seküler modern toplum kendi geleneğini, kendi ideolojisini 'icat' etmeliydi. Türkiye'de sosyoloji, daha doğrusu pozitivist sosyoloji tam da böyle bir misyonla donatılmıştır; sosyoloji seküler modern toplumun resmi ideolojisinin, geleneğinin icat edilmesinin bir aracı olarak fonksiyon kazanmıştır. "Türkiye'de sosyoloji Türk modernleşmesinin önemli kaynaklarından birini oluşturdu; ulus-devletin kuruluş sürecinde de resmî ideolojinin kurucu öğelerinden önemli bir bölümünü sağladı" (Durakbaşa 1998, 100). Atatürk'ün 'fikir babası' olarak tanımladığı Ziya Gökalp'in Türkiye'de sosyolojinin akademik olarak kurucusu olduğunu düşünürsek, sosyolojinin ta başlangıçlarından itibaren saf bir akademik ilgi alanı olmaktan çok 
bir ulus-devlet programının 'bilimsel', ideolojik çerçevesi olarak algılandığını vurgulamamız gerekir. N. Berkes'in işaret ettiği gibi genel olarak “Türkiye'de toplumsal bilimler ulusun toplumsal yaşamında ortaya çıkan sorunlarla ilgili olarak doğup gelişmiştir" (Berkes 1985, 135) ve bu bakımdan o bir akademik ilgi alanı olarak da ulus-devletin kurumsal inşasına hizmet etmiştir. Türkiye'de toplumsal ve politik ihtiyaçlara göre millî bir forma büründürülen sosyolojiyi Çelebi (1998), 'Türkleştirilmiş Comte-Durkheim Sosyolojisi' olarak adlandırmaktadır. Sosyolojinin akademik bir ilgi alanı olarak kurulmasından itibaren gerçekleştirilen sosyolojik çalışmaların, yazılan sosyoloji el kitaplarının içeriğine göz attığımızda karşımızı çıkan tabloda bunu açıkça görebiliriz (İlyasoğlu 1998, 81-99). Türk modernleşmesi ve pozitivist sosyoloji arasındaki ilişki hakkındaki bu kısa değerlendirmemizi şu saptamayla noktalayalım: Türk modernleşme tarihine sosyal düşünce ve kurumlar tarihi olarak bakllırsa, Comtevari bir bireykarşıtı, organisist toplum görüşünün modernleşmeci reformist düşünürlerin düşüncelerinde ve Türkiye Cumhuriyeti'nin resmi ideolojisinde hakim olduğu görülür. 1930-50'lerde yayınlanan sosyoloji ders kitapları, pozitivist sosyolojinin yaygınlaştırılması için çok bilinçli ve sistematik bir çabanın varlığını ve yeni bir toplum anlayışl ve kültürünün orta ögretimden üniversiteye tüm eğitim basamaklarında topluma aşılanmaya çalışıldığını gösteriyor. Sosyoloji Cumhuriyet'in siyasi kadrolarının lâikleştirme çabalarında çok önemli bir kaynak olmuştur ve adeta toplumsal evrimde geri bir aşama olarak değerlendirilen 'din'in yerini almıştır. Robert Wilson'ın dediği gibi "Sosyoloji, modern toplumun teolojisidir" ve Cumhuriyet Türkiye'sinde gerçekten sosyolojinin modernleşen Türkiye toplumu için adeta 'teoloji' yerine geçtiğini, en azından resmi ideolojinin oluşumunda ve modernist seçkinlerin entelektüel kimliklerinde din yerine bir öğreti olarak çok önemli etkisi olduğunu söyleyebiliriz" (Durakbaşa 1997, 141). 


\section{KAYNAKÇA}

Ahmad F. (1995). Modern Türkiye’nin Oluşumu. Çev. Yavuz Alogan. İstanbul 1995.

Akarsu B. (1997). Atatürk ve Türk Devrimi. İstanbul 1997.

Aktar C. (1993). Türkiye’nin Batılılaştırılması. İstanbul 1993.

Aktay Y. (2002). “Türk Sosyolojisinin Özdüşünümselliğine Katkı”. Tezkire 25 (2002) 62-76.

Arslan A. (1981). "Atatürk ve Çağdaş Uygarlık”. E.Ü. Sosyal Bilimler Fakültesi Dergisi 2 (1981) 45-85.

Arslan H. (1992). Epistemik Cemaat: Bir Bilim Sosyolojisi Denemesi. İstanbul 1992.

Berkes N. (1978). Türkiye'de Çă̆daşlaşma. İstanbul 1978.

Berkes N. (1985). Felsefe ve Toplumbilim Yazlları. İstanbul 1985.

Birand K. (1998). Aydınlanma Devri Devlet Felsefelerinin Tanzimatta Tesirleri, Kamran Birand Külliyatı. Ankara 1998.

Bolay S. H. (2008). Türkiye'de Maddeci ve Ruhçu Görüşün Mücadelesi. Ankara 2008.

Çelebi N. (2001). Sosyoloji ve Metodoloji. Ankara 2001.

Çelebi N. (1998). "Sosyoloji Ders Kitaplarında Köy ve Kente Bakış”. Haz. Z. Rona. Bilanço 1923-1998: 'Türkiye Cumhuriyeti'nin 75 Yllına Toplu Bakış' Uluslararası Kongresi Cilt II: Ekonomi-ToplumÇevre (1998) 199-215. İstanbul.

Durakbaşa A. (1998). “Türkiye'de Sosyolojinin Kuruluşu ve Comte-Durkheim Geleneği”. Haz. I. K. Şahin, S. Sökmen \& T. Bora. Sosyal Bilimleri Yeniden Düşünmek Sempozyum Bildirileri (1998) 99115.

Durakbaşa A. (1997). “Klasik Teoriler Feminizmle Karşılaşıyor: Comte’un Pozitivizmin Ilmihali Kitabı Üzerine Feminist Okuma Denemesi”. Toplum ve Bilim 75 (1997) 134-144.

Durukan K. (2002). “Türk Liberalizminin Kökenleri”. Ed. M. Ö. Alkan. Modern Türkiye'de Siyasi Düşünce, 1: Tanzimat ve Meşrutiyet'in Birikimi (2002) 143-155. İstanbul.

Fındıkoğlu Z. F. (1962). Auguste Comte ve Ahmet Riza. İstanbul 1962.

Göle N. (1986). Mühendisler ve İdeoloji. Çev. Eli Levi. İstanbul 1986.

Güngör E. (1982). Dünden-Bugünden: Tarih Kültür ve Milliyetçilik. Ankara 1982.

Hanioğlu M. Ş. (1981). Bir Siyasal Düşünür Olarak Doktor Abdullah Cevdet ve Dönemi. İstanbul 1981.

Hilav S. (1995). "Düşünce Tarihi”. Ed. S. Akşin. Türkiye Tarihi 4. Kitap: Çağdaş Türkiye (1995) 357390. İstanbul.

Işın E. (1985). “Osmanlı Materyalizmi”. Tanzimat'tan Cumhuriyet'e Türkiye Ansiklopedisi (Cilt 2) 363370. İstanbul 1985.

Işın E. (2002). “Osmanlı Modernleşmesi ve Pozitivizm”. Tanzimat'tan Cumhuriyet'e Türkiye Ansiklopedisi (Cilt 2) 350-362. İstanbul 2002.

İhsanoğlu E. (1991). “Modern Bilimlerin Türkiye’ye Girişi”. Haz. İsmail Coşkun. 75. Yılında Türkiye'de Sosyoloji (1991) 85-124. İstanbul.

İlyasoğlu A. (1998). "Türkiye'de Sosyolojinin Tarihini Yazmak: Bir Sorunsallaştırma ve Yaklaşım Önerisi”. Haz. I. K. Şahin, S. Sökmen \& T. Bora. Sosyal Bilimleri Yeniden Düşünmek Sempozyum Bildirileri (1998) 81-97. İstanbul.

Kadığlu A. (1999). Cumhuriyet Iradesi Demokrasi Muhakemesi. İstanbul 1999.

Kahraman H. B. (2002). "Bir Zihniyet, Kurum ve Kimlik Kurucusu Olarak Batılılaşma”. Ed. U. Kocabaşoğlu. Modern Türkiye’de Siyasi Düşünce, 3: Modernleşme ve Batıcılık (2002) 125-140. İstanbul.

Karakuş R. (1995). Felsefe Serüvenimiz. İstanbul 1995.

Kasaba R. (1998). "Eski ile Yeni Arasında Kemalizm ve Modernizm”. Eds. Sibel Bozdoğan \& Reşat Kasaba. Türkiye'de Modernleşme ve Ulusal Kimlik (1998) 12-28. İstanbul.

Kaynardağ A. (1982). “Türkiye’de Felsefenin Öyküsü”. Ed. S. Hilav. Yazko Felsefe Yazıları 1 (1982) 7390. İstanbul.

Korlaelçi M. (1986). Pozitivizmin Türkiye’ye Girişi. İstanbul 1986.

Korlaelçi M. (2002). “Pozitivist Düşüncenin İthali”. Ed. M. Ö. Alkan. Modern Türkiye’de Siyasi 
Düşünce, 1: Tanzimat ve Meşrutiyet'in Birikimi (2002) 214-222 İstanbul.

Köker L. (1990). Modernleşme, Kemalizm ve Demokrasi. İstanbul 1990.

Mahçupyan E. (1998). Türkiye’de Merkeziyetçi Zihniyet, Devlet ve Din. İstanbul 1998.

Mahçupyan E. (2000). Zihniyet Yapıları ve Değişim. İstanbul 2000.

Mardin Ş. (1985). “19. Yüzyılda Düşünce Akımları ve Osmanlı Devleti”. Tanzimat'tan Cumhuriyet'e Türkiye Ansiklopedisi (Cilt 2) 342-351. İstanbul 1985.

Mardin Ş. (1983). "Batıcılık”. Cumhuriyet Dönemi Türkiye Ansiklopedisi (Cilt 1) 245-250. İstanbul 1983.

Mardin Ş. (1991). Türkiye’de Toplum ve Siyaset: Makaleler 1. İstanbul 1991.

Mert N. (1994). Laiklik Tartışmasına Kavramsal Bir Bakış. İstanbul 1994.

Mert N. (1993). "Laik Cumhuriyetin Resmi Bilimi: Sosyoloji”. Dergâh 3/35 (1993) 17-18.

Ortaylı İ. (1983). Imparatorluğun En Uzun Yüzyılı. İstanbul 1983.

Özden B. A. \& Lök A. (2001). “Ahmet Rıza”. Ed. M. Ö. Alkan. Modern Türkiye'de Siyasi Düşünce, 1: Tanzimat ve Meşrutiyet'in Birikimi (2001) 120-128. İstanbul.

Özlem D. (2002). “Türkiye'de Pozitivizm ve Siyaset”. Ed. U. Kocabaşoğlu. Modern Türkiye'de Siyasi Düşünce, 3: Modernleşme ve Batıcılık (2002) 452-464. İstanbul.

Parla T. (1989). Ziya Gökalp, Kemalizm ve Türkiye'de Korporatizm. İstanbul 1989.

Sezer B. (1989). “Türk Sosyologlar1 ve Eserleri I”. Sosyoloji Dergisi 3/1 (1989) 1-96.

Swingewood A. (1998). Sosyolojik Düşüncenin Kısa Tarihi. Çev. Osman Akınhay. Ankara 1998.

Şener S. (1998). Sosyoloji: Sosyal Bilimlere Alternatif Bir Yaklaşım. İstanbul 1998.

Tanör B. (2000). Osmanll-Türk Anayasal Gelişmeleri. İstanbul 2000.

Timur T. (1983). “Atatürk ve Pozitivizm”. Cumhuriyet Dönemi Türkiye Ansiklopedisi (Cilt 1) İstanbul 1983.

Timur T. (1997). Türk Devrimi ve Sonrast. Ankara 1997.

Toker N. \& Tekin S. (2002). "Batıcı Siyasi Düşüncenin Karakteristikleri ve Evreleri”. Ed. U. Kocabaşoğlu. Modern Türkiye’de Siyasi Düşünce, 3: Modernleşme ve Batıcılık (2002) 82-106. İstanbul.

Toku N. (1996). Türkiye'de Anti Materyalist Felsefe (Spiritüalizm). İstanbul 1996.

Toprak Z. (2002). “Osmanlı'da Toplumbilimin Doğuşu”. Ed. M. Ö. Alkan. Modern Türkiye'de Siyasi Düşünce, 1: Tanzimat ve Meşrutiyet'in Birikimi (2002) 310-327. İstanbul.

Tunaya T. Z. (1991). Íslamcılık Akımı. İstanbul 1991.

Ülken H. Z. (1998). Türkiye'de Çağdaş Düşünce Tarihi. İstanbul 1998.

Zürcher E. J. (2001). “Kemalist Düşüncenin Osmanlı Kaynakları”. Ed. A. İnsel. Modern Türkiye'de Siyasi Düşünce, 2: Kemalizm (2001) 44-55. İstanbul. 